\title{
Discrimination in the Eyes of the Law: How "Color Blindness" Discourse Disrupts and Rationalizes Social Stratification
}

\author{
Reva B. Siegel $\dagger$
}

I am quite pleased to have this opportunity to comment on Robert Post's provocative Lecture, Prejudicial Appearances. ${ }^{1}$ Post's effort to distinguish the "dominant conception" of antidiscrimination law from what he presents as a "sociological" account of the field intersects in striking ways with my own efforts to analyze status relations and their disestablishment from a sociohistorical vantage point. In this Response, I would like to identify some key points of similarity and difference in our accounts, with a view to furthering consideration of what we might learn from a sociological approach to the field.

I have learned more than I can express from working with Robert Post over the years, yet I still find myself startled-sometimes with exasperation, most often with delight - at the ways our intuitions about things of this world diverge and converge. In the long tradition of our long arguments, this Response begins by emphasizing an important difference in our approaches to the question explored in his Lecture, and winds up identifying a deep ground of methodological agreement between us.

As I explore in the first Part of this Response, my own efforts to model antidiscrimination law from a dynamic, or sociohistorical, vantage point take as central to the field the problem of social stratification, a concept missing from Post's sociological account. In the remainder of this Response, I argue that one needs a concept of social stratification-of status inequality among groups arising out of the interaction of social

Copyright $\odot 2000$ Califomia Law Review, Inc.

$\rightarrow \quad$ Nicholas deB. Katzenbach Professor of Law, Yale Law School. This essay is written in loving memory of my father. I would especially like to thank Jack Balkin and Robert Post and the precious circle of friends who were generous enough to engage me this year about the questions that haunted the writing of this essay, and much more: Bruce Ackerman, Lisa Cardyn, Ariela Dubler, Owen Fiss, Bob Gordon, Ian Haney Lopez, Angela Harris, Dan Kahan, Lisa Orsaba, Carol Rose, Marge Shultz, and Kenji Yoshino.

1. Robert Post, Prejudicial Appearances: The Logic of American Antidiscrimination Law, 88 CALIF. L. Rev. I (2000). 
structure and social meaning - in order to make sense of the blindness trope at the heart of antidiscrimination law.

In Part II of this Response, I offer such an account-an account that demonstrates how color blindness discourse functions as a semantic code and then illustrates how this semantic code can be used to characterize practices in ways that may either disrupt or rationalize social stratification. Color blindness discourse may offer symbolic or expressive testimony of this society's desire to achieve neutrality in matters of race relations, but, I argue, color blindness discourse cannot itself generate a positive account of what race-neutrality would look like in practice. The conviction that color blindness discourse does offer such positive, practical guidance generally reflects views about the social nature of race that are entirely independent of the conceptual premises of color blindness discourse.

Part III of this Response continues this sociohistorical analysis of color blindness discourse, examining how color blindness discourse works to disrupt or rationalize social stratification over time and under changing sociohistorical conditions. Here I consider how sociohistorical inquiry might illuminate the familiar debate between antidiscrimination and antisubordination principles that for more than two decades has dominated arguments about equality in popular, academic, and judicial fora. I argue that a sociological account of antidiscrimination law-that attends to questions of group inequality as well as to the ways that the practices and meanings that sustain group inequality evolve as they are contested-can teach us much more about the underlying purposes of antidiscrimination law than Post's Lecture suggests. On my account, a commitment to alleviating stratification is and has been central to the project of antidiscrimination law since the beginning of the Second Reconstruction. But the very method of analysis that demonstrates the centrality of this normative commitment to the antidiscrimination project simultaneously reveals the limitations of meta-principles (such as "antidiscrimination" or "antisubordination") in guiding our critical practices. In short, on my account, sociohistorical analysis reveals both the utility and the limits of meta-principles that might guide positive and normative analysis of equality.

In the final analysis, I concur with Post's view-so compellingly argued in his First Amendment scholarship-that a meta-principle abstracted from social practice cannot help us resolve many of the most pressing and controverted questions in law. At its best, a sociological, or sociohistorical, account of the problems addressed by antidiscrimination law reveals to us the nest of more particularized positive and normative questions to which tropes of blindness often blind us. At the end of the day, we must forge answers to these questions in history: as we argue over the justice of particular social relations, particular social practices, and 
particular social meanings, and as such conflicts produce changes in the very relations, practices, and meanings that sustain status inequality over time.

SOCIOLOGICAL APPROACHES to DisCRIMINATION

This Response opens with a brief sketch of Post's Lecture that cannot possibly do its full argument justice but does, I hope, identify the basic analytical framework that Post has identified as a "sociological" account of antidiscrimination law. I then draw upon my own prior work to sketch, in similarly brief terms, a sociohistorical account of antidiscrimination law that diverges from Post's in one especially crucial dimension. On my account, the concept of social stratification is key to understanding antidiscrimination law and color blindness discourse, as I then undertake to demonstrate in the remaining Parts of this Response.

\section{A. Post's Account of Antidiscrimination Law}

In Prejudicial Appearances, Post offers an account of the "dominant conception" of antidiscrimination law derived from the case law itself. Antidiscrimination law, he observes, "seeks to neutralize widespread forms of prejudice that pervasively disadvantage persons based upon inaccurate judgments about their worth or capacities" by "eliminating or carefully scrutinizing the use of stigmatizing characteristics as a ground for judgment." As the Supreme Court explains: "In passing Title VII, Congress made the simple but momentous announcement that sex, race, religion, and national origin are not relevant to the selection, evaluation, or compensation of employees."

Antidiscrimination law thus requires employers "to make decisions as if their employees did not exhibit forbidden characteristics, as if, for example, employees had no race or sex." "This," Post observes, "is what underwrites the important trope of "blindness' .... Blindness renders forbidden characteristics invisible; it requires employers to base their judgments instead upon the deeper and more fundamental ground of 'individual merit' or 'intrinsic worth." The law would have employers judge employees on the basis of what it deems to be relevant, rational, and legitimate criteria-the employee's ability to perform the job. As the Court observed in Griggs, "Congress has not commanded that the less qualified be preferred over the better qualified simply because of minority origins.

\footnotetext{
2. Id. at 8 .

3. Id. at 9 .

4. Price Waterhouse v. Hopkins, 490 U.S. 228, 239 (1989) (Brennan, J., plurality opinion).

5. Post, supra note 1, at 11.

6. Id.
} 
Far from disparaging job qualifications as such, Congress has made such qualifications the controlling factor, so that race, religion, nationality, and sex become irrelevant."7

In passing, Post questions whether law ought to encourage employers to apprehend their employees in such purely instrumental terms, ${ }^{8}$ but his challenge to the field is more fundamental. In Prejudicial Appearances, Post contends that antidiscrimination law does not and cannot cause employers to make judgments about qualifications in a manner that is completely race and sex-blind: "Law is made by the very persons who participate in the social practices that constitute race, gender, and beauty. It would be astonishing, therefore, if American antidiscrimination law could transcend these categories, if it could operate in a way that rendered them truly irrelevant."

On Post's "sociological" account of the field, antidiscrimination law instead "alter[s] the norms by which sex is given social meaning." Enforcement of the employment discrimination statute does not eliminate " "the entire spectrum of disparate treatment of men and women resulting from sex stereotypes,","l at least if "stereotypes" are understood as Post defines them-" "the conventions that underwrite the social practice of gender." 12 Instead, as Post illustrates through an analysis of the cases enforcing Title VII's prohibition against discrimination on the basis of sex, ${ }^{13}$ Title VII interacts with "gender practices... in a selective manner." 14 The case law interpreting Title VII bars many gender-specific employment practices, but it authorizes others-notoriously, the enforcement of gender-specific dress and grooming codes, ${ }^{15}$ and gender-specific job assignments intended to protect customer privacy interests. ${ }^{16}$ In short, enforcement of the federal employment discrimination statute may disrupt and transform existing gender norms, but it does not wholly obliterate them.

This, Post argues, is as it should be. On the sociological account, the law "does not ask whether 'stereotypic impressions' can be eliminated tout court, but rather how the law alters and modifies such impressions."17 Antidiscrimination law is a "social practice, which regulates other social

7. Griggs v. Duke Power Co., 401 U.S. 424, 436 (1971).

8. See Post, supra note 1, at 13-14.

9. Id. at 17.

10. Id. at 20.

11. County of Washington v. Gunther, 452 U.S. 161, 180 (1981) (quoting Los Angeles Dep't of Water \& Power v. Manhart, 435 U.S. 702, 707, n.13 (1978)) (emphasis removed).

12. Post, supra note 1 , at 18.

13. See id. at 18-30.

14. Id. at 26.

15. See id. at 24-29.

16. See id. at 25-26.

17. Id. at 31 . 
practices"; courts should therefore strive to "reshape [race and gender] in ways that reflect the purposes of the law."18

Post goes on to offer reasons, apart from simple descriptive accuracy, for embracing this "sociological" account of antidiscrimination law over the "dominant conception" of the field. ${ }^{19}$ But before assessing those reasons, I would like first to consider how Post's sociological account of the field both converges with and diverges from my own.

\section{B. Supplementing the Sociological Account: Stratification in Sociohistorical Perspective}

For some years now, I have used legal-historical methods to explore problems in antidiscrimination law. When I first turned to history, it was to explore changes in race and gender relations during periods when conversation about social status was far more explicit than it is today. But, as I began to examine the changing structure of gender and race relations in late nineteenth-century America, it occurred to me that I was examining a historical moment that is in important respects not unlike our own. In the aftermath of the Civil War, the nation began to experiment with disestablishing race and gender inequality. Law reform in this era sought to make whites and blacks more equal before the law, and in more halting ways, to affirm notions of sex equality, particularly in marriage. By looking at how the legal system began to disestablish gender and race inequality in the nineteenth century, we can learn something about the operations of antidiscrimination law today.

With questions of this sort in view, I have explored changes in the regulation of reproduction, violence, work, suffrage, and citizenship in the period after the Civil War. ${ }^{2 n}$ For the purposes of this Response, I will draw

18. Id. at 17 .

19. See id. at $30-40$.

20. See, e.g., Reva B. Siegel, Abortion as a Sex Equality Right: Its Basis in Feminist Theory, in Mothers in LAW: Feminist Theory AND the LEgal Regulation of Motherhood 43 (Martha Albertson Fineman \& lsabel Karpin eds., 1995) [hereinafter Siegel, Abortion as Equality Right]; Reva B. Siegel, Collective Memory and the Nineteenth Amendment: Reasoning About "the Woman Question" in the Discourse of Sex Discrimination, in HistoRy, MEMORY, AND THE LAW 131 (Austin Sarat ed., forthcoming 1999) (hereinafter Siegel, Collective Memory]; Reva B. Siegel, Home as Work: The First Woman's Rights Claims Concerning Wives' Household Labor, 1850-1880, 103 Y ALE L.J. 1073 (1994) [hereinafter Siegel, Home as Work]; Reva B. Siegel, Reasoning from the Body: An Historical Perspective on Abortion Regulation and Questions of Equal Protection, 44 STAN. L. REv. 261 (1992) [hereinafter Siegel, Reasoning from the Body]; Reva B. Siegel, The Modemization of Marital Status Law: Adjudicating Wives' Rights to Eamings, 1860-1930, 82 GEo. L.J. 2127 (1994) [hereinafter Siegel, Modernization]; Reva B. Siegel, The Racial Rhetorics of Colorblind Constitutionalism: The Case of Hopwood v. Texas, in RACE AND REPRESENTATION: AfFiRMATIVE ACtIon 29 (Robert Post \& Michael Rogin eds., 1998) [hereinafter Siegel, Colorblind Constitutionalism]; Reva B. Siegel, "The Rule of Love": Wife Beating as Prerogative and Privacy, 105 Y ALE L.J. 2117 (1996) [hereinafter Siegel, Rule of Love]; Reva B. Siegel, Valuing Housework: Nineteenth-Century Anxieties About the Commodification of Domestic Labor, 41 AM. Behav. ScI. 1437 (1998); Reva B. Siegel, Why Equal Protection No Longer Protects: The Evolving 
from my work several observations about the nature of race and sex discrimination, sociohistorically considered. This exercise will reveal deep grounds of agreement with the sociological account Post offers in Prejudicial Appearances, but it will also expose some important grounds of difference.

Post describes antidiscrimination law as a social practice that regulates the social practices of race and gender, altering the conventions that give such practices meaning. ${ }^{21}$ While this is a helpful account, it is also terribly abstract and silent about certain fundamental features of the undertaking.

Considered concretely, antidiscrimination law regulates the social practices that sustain the relative social position of whites and blacks, men and women. A bit more abstractly, we might say that antidiscrimination law regulates the social practices that sustain group inequality. The group inequalities that concern antidiscrimination law are typically those that are socially pervasive (articulated across social domains) and socially persistent (articulated over time). When inequality among groups is structurally pervasive and persistent in this way, we typically refer to it as a condition of social stratification.22

When we analyze race and gender inequality from a historical standpoint, we encounter relations of group inequality embedded in the social organization of work, reproduction, and sexuality as such activities are structured in institutions such as slavery, the market, or marriage. Indeed, from the standpoint of history, what is perhaps most visible is the sheer heterogeneity of institutions, practices, stories, and reasons that sustain the unequal social position of different groups over time. Couched a bit more abstractly, we might say that social stratification is constituted through features of (1) social structure (institutions or practices) and (2) social meaning (stories or reasons). The elements of social structure and social meaning that sustain stratification vary by group and within groups, and they evolve over time as their legitimacy is contested. In short, when considered from a historical standpoint, discrimination has no transcontextual or fixed form. ${ }^{23}$

Forms of Status-Enforcing State Action, 49 STAN. L. REv. 1111 (1997) [hereinafter Siegel, Equal Protection].

21. See Post, supra note 1 , at $16-30$.

22. For an overview of some of the recent sociological literature on stratification, see Social Stratification: Class, Race, and Gender in Sociological Perspective (David B. Grusky ed., 1994).

23. See, e.g., Siegel, Equal Protection, supra note 20, at 1119; Siegel, Modernization, supra note 20, at 2210-11; Siegel, Rule of Love, supra note 20, at 2179. In other words, 1 reject the legal-formalist assumption that, through abstract ("principled") reasoning, we can adduce the kinds of social groups at which discrimination is directed or the kinds of social forms it assumes. Rather, these understandings emerge through social struggle, as various features of social stratification are contested over time. 
A look at history discloses that the network of institutions, practices, and meanings that support social stratification varies by group, and within groups as well. There are a variety of institutions (e.g., market, family), practices (e.g., separation, role differentiation) and reasons (e.g., degradation, paternalism) employed to enforce the different social status of groups. And because persons are members of multiple status groups, there may well be considerable variation in the institutions, practices, and meanings that regulate the social position of different members of one group. ${ }^{24}$

Furthermore, the institutions, practices, and reasons that support group stratification vary over time as their legitimacy is contested. At any point in history, a society may view inequality in the distribution of social goods as lawful or illicit, just or unjust. Inequality in the distribution of material and dignitary goods among groups is periodically contested, and when the legitimacy of a particular distributive regime is successfully challenged, status-enforcing practices often evolve in rule structure and rationale, a dynamic I have called "preservation-through-transformation."25 Successful challenges to the legitimacy of a distributive regime redefine what counts as a fair or just practice or rationale for allocating social goods, and practices and reasons once thought reasonable are thus periodically recharacterized as wrongful. ${ }^{26}$

Since the Civil War, the American legal system has played an increasingly self-conscious role in regulating the distributive regimes that sustain group stratification. Of course, law works both to disestablish and to legitimate the distributive regimes that sustain group stratification. Consider, for example, the transition from slavery to segregation. As law confers formal equality on groups, it disturbs the institutions, practices, and meanings that maintain social stratification, and, to the extent it does so, incremental changes in the relative social position of groups may result. ${ }^{27}$

"Discrimination" and "prejudice" are names that we use to brand as illegitimate, practices and reasons that American society once viewed as perfectly legitimate.

24. See, e.g., Siegel, Abortion as Equality Right, supra note 20, at 58-59 (observing that the nineteenth-century campaign to criminalize abortion focused on birth-control practices of privileged women, and cautioning that it is important to ascertain the class and race salience of reproductive regulation, which can be "birth-compelling or birth-deterring in form"); Siegel, Home as Work, supra note 20, at 1189-1205 (observing that during the Reconstruction era, when the woman's rights movement began to assert that wives' household labor inhibited them from attaining equality with their husbands, the inovement's leadership advocated a reorganization of the family sphere in which women would perform household labor on a collective basis, with poor working women performing manual aspects of household labor for pay under the direction of "edueated" women); Siegel, Rule of Love, supra note 20, at 2134-41, 2150-70 (observing that during the Reconstruction era, the legal system punished at the whipping post poor and minority men accused of wifebeating, while extending privacybased immunities to inore privileged men accused of similar conduct).

25. Siegel, Rule of Love, supra note 20, at 2175-88.

26. See, e.g., Siegel, Equal Protection, supra note 20, at 1146-48.

27. See generally id. (illustrating how, during both the First and Second Recoustruction, interpretation of the Equal Protection Clause disturbed and preserved the subordinate social position of African Americans); Siegel, Colorblind Constitutionalism, supra note 20, at 48-57 (tracing discourse of 
II

\section{Analyzing Color Blindness Through the Lens of Stratification}

When the sociological account of antidiscrimination law that Post offers in Prejudicial Appearances is elaborated in these ways, we can say something more about how the practice of "blindness" works to transform and preserve relations of race and gender inequality. The concept of stratification or group inequality that is missing from Post's account plays a key role here. One needs a concept of social stratification, of status inequality among groups arising out of the interaction of social structure and social meaning, in order to make sense of the blindness trope at the heart of antidiscrimination law. For "[i]t is the social condition of racial stratification that makes the concept of colorblindness intelligible as a distributive principle." ${ }^{28}$ When we say we are distributing goods and opportunities in a race- and gender-blind fashion, we recognize group identity but ignore the ordinary status consequences of group identity for purposes of the relevant social transaction. ${ }^{29}$ Differently put, blindness tropes are concerned with counteracting the normal status-linked benefits and detriments of group membership. ${ }^{30}$

Even so, practices of group-blind distribution generally alleviate group stratification without eradicating it. How is this so? The blindness trope is, as I have argued, no less a legal fiction than the doctrine of marital unity or the concept of equality in the eyes of the law. ${ }^{31}$ As I will now illustrate, instability and slippage in discourses of race and gender, as well as the idiom of discrimination itself, allow this society to embrace principles of group-blind distribution without disestablishing group stratification. In short, antidiscrimination law contains its own complex mode of representing race and gender and of representing their transcendence, and these representations play a crucial part in the social construction of race and gender. ${ }^{32}$

racial privacy during the First and Second Reconstructions, and illustrating how an understanding of racial equality at law in each era presupposed the perpetuation of racial inequality in social fact). For an account of changes in gender status law during this period, see Siegel, Rule of Love, supra note 20.

28. Siegel, Colorblind Constitutionalism, supra note 20, at 51.

29. See id.

30. Cf. Joseph Tussman \& Jacobus tenBroek, The Equal Protection of the Law', 37 CALIF. L. REv. 339, 354 (1949) (proposing doctrines of "suspect classification" and "rigid scrutiny" whose "content, at any particular time, will depend upon the area in which the principle of cquality is struggling against the recurring forms of claims to special and unequal status-whether along racial, religious, economic, or even political, lines").

31. See Reva B. Siegel, In the Eyes of the Law: Reflections on the Authority of Legal Discourse, in Law's Stories: Narrative and Rhetoric in the Law 225, 227 (Peter Brooks \& Paul Gewirtz eds., 1996).

32. Cf. Michael Omi \& Howard Winant, Racial Formation in the United States: From THE 1960s TO THE 1990s, at 55-56 (2d ed. 1994) (advocating an approach to "racial formation" that understands race as growing out of interaction of "both social structure and cultural representation"). 
In the ensuing discussion I will first illustrate the important role that representational conventions play in debates over the legitimacy of distributive practices, and then proceed to consider in more detail how the discourse of color blindness itself works to disrupt and to rationalize the practices that sustain group inequality.

\section{A. Representational Conventions in Debates About the Legitimacy of Distributive Practices}

Debates over the practices that sustain group inequality generate their own representational conventions-representations of the social groups in question as well as of those aspects of social structure and social meaning that sustain the groups' relative social status. For example, even those with no formal training in law understand that "crack cocaine" is a "race neutral" concept in the criminal justice system, but race-identified in social practice. Similarly they understand that "domestic labor," "child care," "rape," and "single parent" are "gender neutral" in law and genderidentified in social practice. Given the explosive questions about distribution that drive debates about the legitimacy of the practices that sustain group inequality, it is not terribly surprising that a society would develop specialized ways of arguing about the justice of its social practices and the modes of regulation to which they are properly subject. More striking is the way that linguistically competent actors-with and without formal training in law-manipulate these representational conventions in debates about the justice of distributive practices. Those engaged in argument continually exploit semantic instability in the positive and normative terms employed to characterize groups and practices, yet participants in the debate appear to be only intermittently cognizant of the degree to which this is so.

To start with a seemingly simple case, what does it mean when we say that a rule classifies "on the basis of" race or sex? We often talk as if the meaning of this claim were transparent and uncontroverted; in fact it is not. Sometimes the Supreme Court reasons that for a rule to classify on the basis of sex, the rule must apply only to group members; but sometimes the Court reasons that the rule must apply to all group members. For example, in equal protection doctrine, the Court uses this dodge to avoid characterizing policies concerning pregnant women as sex-based,$^{33}$ so that, in the eyes of the law, abortion policies are not. ${ }^{34}$ Along similar lines, the

33. See Geduldig v. Aiello, 417 U.S. 484, 496-97 n.20 (1974) ("The program divides potential recipients into two groups-pregnant women and nonpregnant persons. While the first group is exclusively female, the second includes members of both sexes.").

34. See, e.g., Bray y. Alexandria Women's Health Clinic, 506 U.S. 263, 271 (1993) ("While it is true ... that only women can become pregnant, it does not follow that every legislative classification conceming pregnancy is a sex-based classification."' (quoting Geduldig v. Aiello, 417 U.S. at 484, 496 n.20)) (reaffirming Geduldig and applying its holding that classifications pertaining to pregnancy are 
"sex-plus" doctrine, which currently protects sex-specific grooming and dress codes, holds that policies that apply to some but not all group members do not classify on the basis of sex, unless they concern an immutable trait or a fundamental right. ${ }^{35}$ On this account, employers may prohibit women from wearing pants or men from wearing dresses without discriminating on the basis of sex. ${ }^{36}$ (Discrimination on the basis of sexual orientation can be expressed in sex-plus terms-as, for example, a refusal to hire men who desire men-but courts simply exclude homophobic hiring criteria from the ambit of sex-plus doctrine, on the grounds that courts should not extend Title VII to forms of discrimination that Congress did not intend to prohibit.) ${ }^{37}$

Yet as we examine the characterization of practices as distinct from rules, we discover that practices that pertain to some, but not all, group members are often characterized as discriminating "on the basis of sex." Consider, for example, sexual harassment doctrine. A man makes overtures to a woman. By reason of a heterosexual presumption, coupled with what Kenji Yoshino terms a monosexual presumption, ${ }^{38}$ courts assume that a putative harasser will make such overtures only to women. ${ }^{39}$ Still it flies in the face of social understanding to say that he would make such overtures to all women. (Early on, sex-plus doctrine supplied a defense to claims of sexual harassment. ${ }^{40}$ Even if he did so, the law would not characterize such behavior as "discriminating" "on the basis of sex" unless the

not necessarily sex-based to abortion in the course of interpreting animus provision of civil rights statute).

35. See Willingham v. Macon Tel. Publ'g Co., 507 F.2d 1084, 1091 (5th Cir. 1975).

36. See, e.g., Lanigan v. Bartlett \& Co. Grain, 466 F. Supp. 1388, 1391 (W.D.Mo. 1979) (applying "sex-plus" doctrine to uphold discharge of female employee who violated dress code by wearing a pantsuit, reasoning that "plaintiff's affection for pantsuits is not an immutable characteristic"); $c f$. Devine v. Lonschein, 621 F. Supp. 894, 897 (S.D.N.Y. 1985) ("At least until that dreadful day when unisex identity of dress and appearance arrives, judicial officers ... are entitled to some latitude in differentiating between male and female attorneys, within the context of decorous professional behavior and appearance.").

37. See, e.g., DeSantis v. Pacific Tel. \& Tel. Co., 608 F.2d 327, 331 (9th Cir. 1979) ("We must again reject appellants' efforts to 'bootstrap' Title VII protection for homosexuals.... [W] [Wether dealing with men or women the employer is using the same criterion: it will not hire or promote a person who prefers sexual partners of the same sex. Thus this policy does not involve different decisional critera for the sexes.").

38. Courts assume that the harasser is either heterosexual or homosexual, but not bisexual. See Kenji Yoshino, The Epistemic Contract of Bisexual Erasure, 52 STAN. L. REv. (forthcoming Feb. 2000).

39. See, e.g., Oncale v. Sundowner Offshore Servs. 523 U.S. 75, 80 (1998) ("Courts and juries have found the inference of discrimination easy to draw in most male-female sexual harassment situations, because the challenged conduct typically involves explicit or implicit proposals of sexual activity; it is reasonable to assume those proposals would not have been made to someone of the same sex.").

40. See, e.g., Barnes v. Costle, 561 F.2d 983, 990-91 \& n.57 (D.C. Cir. 1977) (citing sex-plus cases and attempting to distinguish problem of sexual harassment). 
recipient, by her conduct, communicated that it was unwelcome. ${ }^{41}$ Recent debates over harassment law merely drive to the surface the socially contingent act of characterization that occurs whenever we make judgments about practices that we claim discriminate on the basis of race or sex-a problem already familiar to us in debates over the concept of discriminatory intent. .2 $^{2}$

So when we say that an employer does not discriminate on the basis of race or sex, what exactly are we saying? As a doctrinal matter, it turns out that we are saying many different, and sometimes contradictory, things-and these terms are likely to have still other meanings to persons not familiar with some of the more arcane ways doctrine characterizes social practices. Yet color- and gender-blind discourse is more than indeterminate; it is partial. Race and gender stratification is sustained by many social practices and reasons, but antidiscrimination law constrains and delegitimates only some of them..$^{43}$ A society may thus embrace groupblind practices of distribution that alter without eradicating the social stratification of groups.

\section{B. Color Blindness: Representing Race in Debates over Practices that Sustain Group Inequality}

Once we begin to attend to the highly specialized ways in which antidiscrimination law represents race and discrimination, we can describe more precisely how color blindness discourse both constrains and legitimates practices that maintain racial stratification. To this end, I will first examine the distinctive ways in which tropes of race are employed in claims about color blindness, and then consider how this rhetorical system is used to characterize the social practices that enforce and perpetuate the differential status of racial groups. This analysis will demonstrate how color blindness discourse works both to destabilize and to rationalize social stratification.

41. Meritor Savings Bank v. Vinson, 477 U.S. 57, 68 (1986) ("The gravamen of any sexual harassment claim is that the alleged sexual advances were 'unwelcome."' (quoting 29 CFR § I604.11(a) (1985))). Opponents of affirmative action such as Justice Scalia are the first to emphasize that gender-differentiating conduct is a necessary but not sufficient condition for liability in the sexual harassment context; the putatively harassing conduct must still be judged unwelcome, offensive, or pervasive before a court will declare that it discriminates on the basis of sex. See Oncale, 523 U.S. at 81 (holding that Title VII "does not reach genuine but innocuous differences in the ways men and women routinely interact with members of the same sex and of the opposite sex. The prohibition of harassment on the basis of sex requires neither asexuality nor androgyny in the workplace; it forbids only behavior so objectively offensive as to alter the 'conditions' of the victim's employment").

42. See, e.g., Siegel, Equal Protection, supra note 20, at 1141 n.57 (discussing the literature criticizing discriminatory purpose doctrine).

43. See, e.g., supra text accompanying notes 25-27, 33-37 and infra text accompanying notes 7181 . 
In order to illustrate the specialized, and often contradictory, ways that antidiscrimination law makes assertions about "race" as it evaluates the justice of our distributive practices, I will be working with some usage distinctions Neil Gotanda identifies in his influential article, $A$ Critique of "Our Constitution is Color-Blind." 44 Gotanda observes that the meaning of the term "race" varies significantly in Supreme Court cases, and in ways that the Court does not generally acknowledge. Gotanda identifies four very different modes of talking about "race" in the antidiscrimination case law, which he calls "status-race," "formal-race," "historical-race," and "culture-race." "Status-race" refers to the kinds of claims about race that the law might link to stereotypes, prejudice, or racism. "Formal-race" is the mode of talking about race that civil rights law has developed to oppose status-race claims; "formal-race" claims attempt to counteract status-race claims by practices of "racial nonrecognition" or color blindness premised on the view that race is socially and morally irrelevant, a matter of appearance or skin color only. "Historical-race" is the way courts talk about race when describing differences in the social situation of racial groups or their individual members that are attributable to past or current discrimination. By contrast, "culture-race" approaches differences in the outlook and mores of racial groups or their individual members as more lasting features of group identity, treating race as a species of ethnicity, a concept at work when racial difference is celebrated as a form of diversity or otherwise judged by critics such as Dinesh D'Souza. ${ }^{46}$

While the ensuing discussion will explore shifting legal usages of the term "race," I note at the outset that one could extend Gotanda's analysis of the different forms of racial rhetoric to the case of gender, especially if one is looking for gender analogues to the concept of "formal-race" and the practice of color blindness or racial nonrecognition. For example, in ruling that gender-based peremptory strikes in jury selection are unconstitutional, Justice O'Connor observed: “We know that like race, gender matters. ... [O]ne need not be a sexist to share the intuition that in certain cases a person's gender and resulting life experience will be relevant to his or her view of the case." ${ }^{37}$ Yet she acknowledged that "[t]oday's decision severely limits a litigant's ability to act on this intuition, for the import of our holding is that any correlation between a juror's gender and attitudes is

44. Neil Gotanda, A Critique of "Our Constitution is Color-Blind," 44 StAN. L. Rev. 1 (1991).

45. Id. at 3-4.

46. See id. at 4. For contrasting usage of the culture-race concept, compare Regents of the University of California v. Bakke, 438 U.S. 265, 316-19 (1978) (Powell, J., concurring) (reasoning that race may be used as a factor in educational admissions to enhance the diversity of the student body). with Siegel, Colorblind Constitutionalism, supra note 20, at 52-55 (discussing commentators such as Dinesh d'Souza who argue that racial hierarchy reflects the cultural "merits" of different racial groups).

47. J.E.B. v. Alabama, 511 U.S. 127, 148-49 (1994) (O’Connor, J., concurring). 
irrelevant as a matter of constitutional law." 48 Restrictions on the peremptory challenge, in matters of gender as in matters of race, amount to "a special rule of relevance, a statement about what this Nation stands for, rather than a statement of fact." 49 In this passage, Justice O'Connor is unusually forthright in acknowledging multiple and specialized modes of talking about race and gender in the case law. Most commonly, antidiscrimination discourse slides-sometimes unconsciously, sometimes adventitiously - from formal to historical or cultural discourses about race and gender, and back again. ${ }^{50}$

It is by observing how these different modes of race talk interact in doctrinal claims about race discrimination that we can begin to understand how color blindness discourse functions as a semantic code. But to crack the code, we first need to consider more carefully how each of these modes of race talk supports or undermines claims about the instrumental rationality of regulatory decisions, claims that-as Robert Post has observednow dominate color blindness talk..$^{51}$ Questions concerning the instrumental rationality of regulatory decisions have come to dominate color blindness discourse as it has been doctrinally elaborated in the Second Reconstruction because of the particular legal-process rationale through which antidiscrimination law has justified judicial review of such decisions. ${ }^{52}$ When antidiscrimination law asks whether discrimination has

48. Id. at 149 .

49. Id. (quoting Brown v. North Carolina, 479 U.S. 940, 941-42 (1986)).

50. See, e.g., Gotanda, supra note 44, at 36-52 (observing the movement between "formal" and "historical" usages of race in debates concerning race-conscious measures such as affirmative action); Siegel, Colorblind Constitutionalism, supra note 20, at 41-47 (illustrating how the decision in Hopwood v. Texas, 78 F.3d 932 (5th Cir. 1996). employs contradictory uses of race in the course of analyzing diversity and remedial justifications for affirmative action).

51. See Post, supra note I, at 13-15.

52. See Bruce A. Ackerman, Beyond Carolene Products, 98 HARv. L. Rev. 713, 713-15 (1985) ("The Carolene solution is to seize the high ground of democratic theory and establish that the challenged legislation was produced by a highly defective process.") (observing that the current rationale for judicial protection of minority rights was developed at a time when the Supreme Court was repudiating constitutional doctrines restricting New-Deal legislation and was therefore preoccupied with the counter-majoritarian difficulty). To appreciate how this legal-process narrative translates questions of discrimination into problems of intrumental rationality, see, for example. Gerald Gunther, The Supreme Court, 1971 Term-Foreword: In Search of Evolving Doctrine on a Changing Court: A Model for a Newer Equal Protection, 86 HARv. L. REv. 1, 20-21 (1972) ("Modest interventionism would certainly differ from the 'all-out tolerance' of the old equal protection and from the attitude of the hands off due process era. It would place a greater burden on the state to come forth with explanations about the contributions of its means to its ends. But that demand would reinforce, not conflict with ... the Court's modern role [in] safeguarding the structure of the political process .... Means scrutiny .... can improve the quality of the political process-without second-guessing the substantive validity of its results. ..."). For accounts that situate the preoccupations of the legal process school in the larger intellectual movements of the post-World War Il era, see MoRToN J. HoRwitz, The Transformation of american Law, 1870-1960: The Crisis of Legal Orthodoxy 250-68 (1992); Edward A. Purcell, The Crisis of Democratic Theory: Scientific Naturalism \& The Problem of Value (1973); Gary Peller, Neutral Principles in the 1950s, 21 U. Mich. J.L. Reform 561 (1988); cf. Post, supra note 1, at 14 and $n .69$ (tracing the blindness trope in antidiscrimination law 
occurred, it typically inquires whether the challenged action differentiates among persons "rationally," examining how persons are grouped or classified with respect to "traits" that might be "relevant" to the "purpose" of the regulatory action or law. ${ }^{53}$ For this reason, I would now like to examine in somewhat more detail the different forms of race talk Gotanda has identified, and then to consider how antidiscrimination law moves among these usages as it makes claims about the instrumental rationality, and distributive justice, of regulatory decisions.

Gotanda calls the mode of speaking about race associated with white supremacy or racial prejudice "status-race." 54 Status-race claims are the conventional ascriptive claims about race that justify a status regime. We might note some additional characteristics of status-race claims. Statusrace claims are often group-categorical; that is, they often attribute traits exclusively to members of one racial group or another. In their most conventional form, status-race claims differentiate superordinate and subordinate groups by attributing to members of each group opposing traits that help explain their relative social status. ${ }^{55}$ Thus, a familiar status-race claim is that whites are hardworking and blacks are lazy.$^{56}$ Status-race claims assume that race is a simple and sensible basis for explaining and organizing social relationships.

Formal-race talk arises as part of this society's effort to delegitimate status-race claims, ${ }^{57}$ and is the mode of talking about race that we associate with civil rights law and color blindness. A familiar assertion within

to a Rawlsian conception of justice; further uoting that Rawls interprets the concept of rationality appropriate to the original position in economic terms, as a question concerning "the most effective means to given ends").

53. For the foundational statement of this approach, see Tussman \& tenBroek, supra note 30, at 347 (presenting discrimination as a problem concerning the instrumental rationality of classifications, and offering a now-famous series of diagrams that "make it possible to assess the rationality of regulatory means given a stipulated regulatory purpose"). For an overview of some of the key cases and law review articles that translated this "legal-process" approach to discrimination into the strictscrutiny framework that still govems the review of claims of race discrimination, see PAUL BREST \& Sanford Levinson, Processes of Constitutional Decisionmaking: Cases and Materials 55479 (3d ed. 1992) (excerpting, inter alia, articles by Tussman \& tenBroek, John Ely, and Gerald Gunther).

54. Gotanda, supra note 44 , at 37.

55. For a detailed account of a status regime as an interlocking series of social meanings, see especially J.M. Balkin, The Constitution of Status, 106 Y ALE L.J. 2313, 2321-35 (1997).

56. Cf. Kimberle Williams Crenshaw, Race, Reform and Retrenchment: Transformation and Legitimation in Antidiscrimination Law, 101 HARv. L. REv. 1331, 1370-74 (1988) (identifying a series of binary oppositions that help constitute the social meaning of white and black); see also J.M. BALKIN, Cultural Software: A TheORY OF IDEOLOGY 216-18, $230-34$ (1998) (discussing binary coding and nested oppositions that constitute race and gender). Not all status-race talk functions to differentiate members of superordinate and subordinate groups. Some status-race talk distinguishes among members of the subordinate group, identifying types who together constitute the group and so explain its subordinate social status. Status-race talk of this variety applies exclusively to group members, although to some but not all group members (for example, "the Uncle Tom" or "the uppity nigger").

57. Cf. supra text accompanying notes 28-29. 
formal-race discourse is: "It is wrong to discriminate on the basis of race because the mere fact of race or skin color has no moral or social relevance." Like status-race talk, formal-race talk reasons about race in group-categorical terms. Formal-race talk assumes that race is a biological or physiological trait that all individuals possess and by which they can be differentiated into groups. ${ }^{58}$ Yet, unlike status-race talk and in direct opposition to it, formal-race talk insists that race is a trait that has no social relevance. ${ }^{59}$ On this view, it is irrational to distinguish persons by race.

A society intent on repudiating conventional status-based understandings of race does have other modes of talking about race. The modes of speech Gotanda identifies as "historical-race" and "culture-race" are two of these. These modes of reasoning view race as a social formation, that is, as an aggregation of traits of potential social relevance. Historical-race understands the traits of racial groups as contingent, as arising out of a status system that is being dismantled over time. This mode of talking about race typically focuses on injuries sustained by members of subordinated groups..$^{(1)}$ By contrast, culture-race is that mode of talking that treats race as akin to ethnicity, as involving the distinctive forms of life that social groups work out over time. ${ }^{61}$ In self-conscious opposition to statusrace talk, historical-race claims and culture-race claims understand the traits that constitute race as group-salient and not group-categorical, as traits that are unevenly distributed in society and correlate closely, but by no means precisely, with racial group membership.

Now let us look more carefully at the special kinds of claims that color blindness or formal-race discourse makes about race, so that we can appreciate how color blindness claims interact with other modes of reasoning about race in arguments over the legitimacy of distributive practices. Color blindness or formal-race discourse is in fact a highly specialized form of race talk that shares some features in common with the status-race usages it was developed to combat. As we have seen, from the standpoint of formal-race discourse, race is a fixed yet radically einpty feature of every person's identity. Like traditional biological conceptions of race, formal-race discourse views race as an empirically determinate feature of persons, but unlike traditional biological conceptions of race, formal-race discourse asserts that race has no socially relevant content. For

58. Paradoxically, color blindness discourse frequently assserts that the only real, although morally and socially irrelevant, aspect of race is appearance, "the mere color of one's skin."

59. See Gotanda, supra note 44, at 6 ("Formal-race implies that 'Black' and 'White' are mere racial classification labels, unconnected to social realities.").

60. See id. at 40 ("[1]n historical-race usage, racial categories describe relations of oppression and unequal power. Historical-race usage of Black does not have the same meaning as usage of white: Black is the reification of subordination; white is the reification of privilege and superordination.").

61. See id. at 56 ("Culture-race includes all aspects of culture, community, and consciousness."). 
example, in Hopwood v. Texas, ${ }^{62}$ the Fifth Circuit quotes Richard Posner asserting this basic tenet of the color blindness creed: "“[T]he use of a racial characteristic to establish a presumption that the individual also possesses other, and socially relevant, characteristics, exemplifies, encourages, and legitimizes the mode of thought and behavior that underlies most prejudice and bigotry in modern America." ${ }^{\text {"x }}$ In the court's view, "[t]he use of race, in and of itself, to choose students simply achieves a student body that looks different. Such a criterion is no more rational on its own terms than would be choices based upon the physical size or blood type of applicants." ${ }^{164}$ Conversely, within color blindness or formal-race discourse, to judge persons "without regard to race" is to judge persons on the basis of socially relevant or meritocratic criteria, or to judge them "as individuals." On this view, "individuals" possess skills and talents and diverse forms of cultural literacy, and any of these features may legitimately form the basis for rational or meritocratic judgments about them. ${ }^{65}$ Color blindness discourse views these various socially relevant properties of individuals (including even certain aspects of their accent and appearance) as distinct and distinguishable from "race" as such. Thus, the Hopwood court reasons that "[w]hile the use of race per se is proscribed, state-supported schools may reasonably consider a host of other factorssome of which may have some correlation with race-in making admissions decisions." ${ }^{\prime 66}$

Within color blindness discourse, the concept of the "individual" does two kinds of work. The discourse of individualism signifies a particular kind of claim about race-neutrality, referring to those characteristics of persons apart from their formal-race. This concept of neutrality, in turn, supports a particular view of distributive fairness: providing opportunities to persons "without regard to race," that is, on the basis of "merit" or "qualifications," "achieved" rather than "ascriptive" characteristics. It is crucial to note that, within color blindness discourse, the right to be treated as an "individual" entitles persons to protection from classification on the basis of formal-race only ${ }^{67}$ It is understood to be the essence of

62. 78 F.3d 932 (5th Cir. 1996).

63. Id. at 946 (quoting Richard A. Posner. The DeFunis Case and the Constitutionality of Preferential Treatment of Racial Minorities, 1974 Sup. Cr. REv. 1, 12).

64. Id. at 945.

65. See supra text accompanying notes 6-7.

66. Id. at 946.

67. The objection to classifying persons on the basis of group membership pertains to classifications on the basis of formal-race only. Consider this typical objection to affirmative action:

If race should be the basis for the allocation of society's goods and opportunities, and if racial groups matter more than individuals, then we must accept affirmative action as it has evolved, even if such acceptance requires us to jettison the best in the American tradition. Race cannot serve this purpose, however, because the mere fact of a person's race is morally uninteresting. 
meritocratic rationality, or so-called "equality of opportunity," to classify persons with respect to "socially relevant characteristics" which are taken as goods, or proxies for goods, in themselves. Thus, the Hopwood opinion deems it an affront to meritocratic ordering to take into account Cheryl Hopwood's race, but perfectly reasonable to discount her grade point average by taking into consideration the fact that she attended a community college and a state university ${ }^{68}$ Indeed, on this nnderstanding of "equality of opportunity," it is the essence of "individualism" to categorize persons and to discriminate among them on the basis of such "socially relevant characteristics." Meritocratic social ordering celebrates this kind of groupbased discrimination, and sees the "individnal" as socially realized through it. ${ }^{69}$ Persons talking about individualism and equality of opportunity in this way often depict the market, at least if constrained by color blindness principles, as a race-neutral mechanism of distribution; on this view, market rationality institutionalizes racial justice..$^{70}$

Terry Eastland, The Case Against Affirmative Action, 34 WM. \& MARY L. REv. 33, 46 (1992); $c f$. William W. Van Alstyne, Affirmative Action and Racial Discrimination Under Law: A Preliminary Review in Selected Affirmative Action Topics in Employment and Business Set Asides: A Consultation/Hearing of the United States Commission on Civil Rights 181 (1985) ("[I]ndividuals are not merely social means; i.e., they are not merely examples of a group, representatives of a cohort. or fungible surrogates of other human beings; each, rather is a person whom it is improper to count or to discount by race." (quoting John E. Morrison, Colorblindness, Individuality, and Merit: An Analysis of the Rhetoric Against Affirmative Action, 79 IowA L. REv. 313, 326 n.93 (1994))).

68. See Lani Guinier, The Real Bias In Higher Education, N.Y. Times, June 24, 1997, at A19 ("Had opponents of affirmative action looked beyond race to see why Ms. Hopwood was not admitted, they would have discovered that she lost points because she went to a community college and a state university. The University of Texas penalized Ms. Hopwood, who grew up under difficult circumstances and worked her way through school, because she graduated from a less competitive but more affordable college."); Siegel, Colorblind Constitutionalism, supra note 20, at 35-36 (noting that opinion "throws racial discrepancies in admissions ranges into stark relief, while treating as equitably inconsequential the variance in admissions opportunities produced by the school's policy of favoring residents and its practice of weighting grades in accordance with the reputation of undergraduate institutions, despite its predictably class salient impact on admissions").

69. To appreciate how restrictive the use of "individualism" is in meritocratic claims about race, try substituting anything understood to be a socially relevant trait for the "formal-race" term in the quotation from Richard Posner that I discuss supra text accompanying note 63. For example, " [T] he use of a[n] [educational degree or test score] to establish a presumption that the individual also possesses other, and socially relevant, characteristics, exemplifies, encourages, and legitimizes the mode of thought and behavior that underlies most prejudice and bigotry in modem America."”

70. See, e.g., supra text accompanying notes 6-7. For two variants of this argument, compare Morris B. Abram, Affirmative Action: Fair Shakers and Social Engineers, 99 HARv. L. Rev. 1312, 1326 (1986) ("As fair shakers see it, removing all barriers to the exereise of civil and political rights and to an individual's ability to participate in the free market system is the best possible way to promote justice"), with Richard A. EPSTEIN, Forbidden Grounds: The Case Against EMPLOYMENT DISCRIMINATION LAWS 59-78 (1992) (arguing that eliminating constraints on market ordering will eliminate invidious race and sex discrimination). For a critical evaluation of such arguments, see Cass R. Sunstein, The Anticaste Principle, 92 MicH. L. REv. 2410, 2413-19 (1994) (evaluating arguments for and against view that free markets eliminate race and sex discrimination). 


\section{Color Blindness as a Method of Characterizing Practices: The Example of Griggs}

Bearing in mind the highly specialized ways in which color blindness discourse reasons about race discrimination, race neutrality, and the traits of individuals and groups, we can now examine how color blindness discourse is employed to characterize particular social practices. We start with the paradigm case of overt racial segregation. In Griggs v. Duke Power Co. ${ }^{71}$ for example, the defendant originally placed all of its black employees in one department, called the "labor department," which had the lowest paying jobs in the company. ${ }^{72}$ Title VII, of course, outlawed practices employing such group-categorical racial distinctions as discriminating on the basis of race-that is, as irrationally treating applicants for employment on the basis of group membership rather than evaluating their merits as individuals. On the effective date of Title VII, the defendant moved to comply with the statute by eschewing use of group-categorical racial distinctions, and by requiring instead that all new applicants to formerly white departments would have to have a high school diploma or certain test scores. ${ }^{73}$ Black applicants then challenged these new employment criteria as violating Title VII.

The district court ruled that by instituting these requirements the defendant did not discriminate on the basis of race. ${ }^{74}$ It is easy to see how this argument runs. The company complied with Title VII by abandoning group-categorical racial distinctions and adopting instead group-salient employment criteria. In requiring a high school degree or certain test scores as a condition of employment in its formerly all-white departments, the company was asking for qualifications that could well be relevant to employment, even if such traits were distributed through the population in a group-salient way. Thus, within a conventional understanding of color blindness, these new requirements were race-neutral, because they were not race-categorical even if they were race-salient. ${ }^{75}$ Further, within a conventional understanding of color blindness, the new requirements treated applicants for employment as individuals because the requirements did not distinguish among applicants by racial group, but instead by traits of potential social relevance, even if these "meritocratic" criteria in turn

71. 401 U.S. 424 (1971).

72. See id. at $426-27$.

73. See id. at $427-28$.

74. See Griggs v. Duke Power Co., 292 F. Supp. 243 (M.D.N.C. 1968).

75. Cf. id. at 248. The district court stated that:

In providing for prospective application only, Congress faced the cold hard fact of past discrimination and the resulting inequities. Congress also realized the practical impossibility of eradicating all the consequences of past discrimination. The 1964 Act has as its purpose Id. the abolition of the policies of discrimination which produced the inequities. 
rested on group-based generalizations about the aptitudes and abilities of the individual applicants who possessed them. As the district court observed,

The two tests used by the defendant were never intended to accurately measure the ability of an employee to perform the particular job available. Rather, they are intended to indicate whether the employee has the general intelligence and overall mechanical comprehension of the average high school graduate, regardless of race, color, religion, sex, or national origin. ${ }^{76}$

In accordance with the conventions of color blindness discourse, the defendant company had thus adopted a race-neutral policy even if the policy continued to exclude most blacks from employment in the higher paying departments of the company. As this example should illustrate, the conventions of color blindness discourse make it possible for this society to characterize practices that enforce racial stratification as the product of "race-neutral" and "nondiscriminatory" principles of social distribution. This is one way in which color blindness discourse rationalizes racial stratification.

Yet in Griggs, the Supreme Court did not accept the lower court's reasoning about the legality of the policy in question. Instead, the Court held that, under Title VII, an employer who adopted facially neutral rules (such as the requirement of test scores or a high school degree) that had a disparate impact on protected classes might still be found to discriminate on the basis of race, unless the employer could demonstrate some business necessity or justification for using the challenged criteria. ${ }^{77} \mathrm{~A}$ particular understanding of race animates the Court's decision: The Griggs opinion points to the history of racially segregated education in the South to illustrate why the use of formally race-neutral criteria might nevertheless be discriminatory or unfair. ${ }^{78}$ Given the unequal distribution of educational opportunity to blacks and whites, employment criteria associated with educational attainment would predictably select among applicants in a racesalient way and so reproduce and perpetuate distributive inequities between blacks and whites. Griggs, in short, recognizes what Gotanda calls "historical-race," discussing race as a social field of distributive injustice (in this instance, imvolving discriminatory or unequal educational opportunity).

Yet at the same time that the Griggs Court begins to discuss race in this thicker, "historical" sense, as arising out of the unequal distribution of socially valuable and relevant opportunities (such as education), the

76. Id. at 250.

77. See Griggs, 401 U.S. at 436.

78. See id. at 430 ("Because they are Negroes, petitioners have long received inferior education in segregated schools ...."). 
opinion simultaneously retains and deploys the discourse of individualism associated with formal-race, as it insists that (1) individuals have merit and qualifications independent of their racial identity; and (2) distributive fairness consists in distributing opportunities on the basis of these raceneutral traits. Mid-course in the opinion, "race" shifts semantic registers, transformed from a thick bundle of socially relevant traits back to a thin, socially irrelevant trait, when the Court observes that "Congress has not commanded that the less qualified be preferred over the better qualified simply because of minority origins. Far from disparaging job qualifications as such, Congress has made such qualifications the controlling factor, so that race, religion, nationality, and sex become irrelevant." ${ }^{179}$ Thus, even as Griggs seemingly recognizes that race is a social formation, it reverts to the discourse of formal-race to assert that market rationality is race-neutral and institutionalizes racial justice. These unannounced discursive shifts are commonplace in the case law and sustain the rhetorical power of color blindness discourse. ${ }^{\mathrm{s}}$

Analyzed from this standpoint, color blindness discourse is a highly specialized mode of characterizing social practices. Consider again the logic of this semantic code in action. Since implementation of federal employment discrimination laws, employers rarely organize the workplace in overtly race-categorical terms. When plaintiffs challenge a seemingly race-salient practice as covertly race-based, a characterization dispute ensues along the lines we have just explored. Only if the evidence seems to support a narrative about the practice as covertly employing groupcategorical racial distinctions (that is, irrational judgments based on "racial prejudice" that by definition serve no socially relevant end and function only to differentiate employees on the basis of formal-race) is the practice judged race-based; if the practice can be explained with respect to any socially relevant end, trait, or purpose, it will be characterized as raceneutral, however race-salient in social incidence the practice might be. So, for example, suppose an employer interviews two black applicants and eight white applicants, and hires a white employee; has he made an employment decision on the basis of race? A fact-finder would have to examine the evidence and characterize the challenged decision as one that was race-neutral because based on socially relevant criteria ("qualifications," however race-salient in character or distribution they might be) or as one that was race-based (meaning that the fact-finder was willing to interpret the evidence as supporting a particular narrative in which the employer would refuse to hire any black applicant simply

79. Id. at 436.

80. See, e.g., sources cited supra note 50. 


\section{"because" that applicant was black, i.e., for no socially relevant reason other than prejudice.) $)^{81}$}

81. Here, once again, the law generally assumes that the irrational, class-based animus would be directed at all class members indiscriminately. See, e.g., Jeffries v. Harris County Community Action Ass'n, 615 F.2d 1025, 1030 (5th $\mathrm{Cir}$. 1980) ("[W]here both the person seeking to be promoted and the person achieving that promotion were women, because the person selected was a woman, we cannot accept sex discrimination as a plausible explanation for [the promotion] decision." (quoting Adams $v$. Reed, 567 F.2d 1283, 1287 (5th Cir. 1978))) (holding that where both applicant promoted and applicant rejected were black, challenged decision could not have resulted from race discrimination; reaching this result by following reasoning of sex-discrimination case): cf. supra text at notes 33-36 (discussing the ways law has characterized policies concerning pregnancy and grooming codes). Intermittently, however, the law does recognize that discrimination could manifest itself in the act of differentiating among class members. Doctrine, however, typically reaches this result by recognizing subclasses within the targeted class and treating discrimination directed against members of such subclasses as actionable. See Walker v. IRS, 713 F. Supp. 403 (N.D. Ga. 1989) (dark-skinned African American employee may bring Title VII action for discrimination based on darkness of skin because Title VII provides employees protection from discrimination based on "color" as well as "race"); Jeffries, 615 F.2d at 1032-35 (observing that "sex plus" cases provide support for view tbat "disparate treatment of a subclass of women could constitute a violation of Title VII" and recognizing "black females as a distinct protected subgroup for purposes of the prima facie case and proof of pretext").

The bizarrely abstract conception of discrimination on which such doctrines are based is part of the formal-race discourse discussed in text. As we have seen, the law generally defines discrimination as the cognitive error or irrationality that occurs when a decision maker differentiates among persons based on formal-race; on this view discrimination involves a misascription of traits, either (1) the assumption that formal-race (or "race per se") has any social relevance or (2) the failure to recognize that individual members of a group may possess instrumentally relevant traits that most group members lack.

Sometimes, however, the law seems to acknowledge that discrimination involves more than a simple breakdown of instrumental rationality, and verges on recognizing discrimination as a problem concerning status conflicts among groups involving the distribution of a society's material and dignitary goods. On this account the cognitive error of discrimination involves giving credence to particular narratives that justify policies and practices which unequally distribute social goods. When law proceeds from this intuition, doctrine treats discrimination/stereotyping as something more than the failure to recognize tbat individual members of a group may have different traits than those generally possessed by group members. On these occasions, the law treats discrimination/stereotyping as a normative, narrative process that involves morally suspect prescriptions and cognitively suspect rationalizations that together justify keeping certain groups in "their proper place." From the standpoint of this sociohistorical and narratological view of discrimination-which approaches the problem of race or sex discrimination as one involving the preferential treatment accorded members of some race/sex groups over others-the law is more adept at recognizing certain reasons for excluding some (although not all) group members as suspect rationalizations or stereotypes. In short, from this standpoint, the legal system recognizes as suspect the claim that particular blacks are lazy-or that particular women are too aggressive.

For a case caught between these two views of discrimination, see Price Waterhouse v. Hopkins, 490 U.S. 228 (1989) (reviewing refusal to promote female employee to partner in accounting firm on grounds that she was too aggressive and had interpersonal difficulties in dealing with staff). In Price Waterhouse, the plurality opinion first defines discriminatory animus as a distinction on the basis of formal-sex: "In saying that gender played a motivaring part in an employment decision, we mean that, if we asked the employer at the moment of decision what its reasons were and if we received a truthful response, one of those reasons would be that the applicant or employee was a woman." $1 d$. at 250 (plurality opinion) (footnote omitted). The plurality opinion then immediately proceeds to discuss discriminatory decision making in terms of the concept of "stereotyping": "[W]e are beyond the day when an employer could evaluate einployees by assuming or insisting that they matched the stereotype associated with their group ... An employer who objects to aggressiveness in women but whose positions require this trait places women in an intolerable and impermissible Catch-22: out of a job if 
Assuming the fact-finder decided that the employer had made the hiring decision on race-neutral grounds (i.e., on the basis of qualifications), plaintiffs would then, of course, have the option of challenging the "facially-neutral," race-salient practice on disparate impact grounds; if the defendant employer could then demonstrate business necessity - that is, characterize the practice as serving some socially relevant, if race-salient, end-the employer's decision will once again be characterized as raceneutral within the usages of formal-race discourse as Griggs has elaborated them.

In a world where no signs identify practices that are "race-based," characterization of contested practices will play a crucial role in the operations of antidiscrimination law. Plainly, in such a world, fact-finders will have considerable latitude in explaining whether practices "discriminate" "on the basis of race." But before we even consider the ancillary racial assumptions that might inform exercise of that interpretive discretion, it is crucial to consider the limited nature of the claim antidiscrimination law makes when the law announces that a practice does not discriminate "on the basis of race."

\section{Color Blindness Discourse and Claims of Distributive Justice}

When the law announces that a practice does not discriminate on the basis of race, it speaks within the usages of formal-race discourse. In its original historical context, this familiar mode of talking about race made sense in debates over distributive justice in ways it no longer does today. As we have seen, formal-race discourse tells a particular story about practices that overtly classify on the basis of race; it deems such practices instrumentally irrational (because the mere color of a person's skin can have no social relevance) and distributively unjust (because the belief on which such practices are predicated-that the mere color of a person's skin has social relevance-is the product of irrational racial prejudice). The claim that "race has no social relevance" can be understood, historically

they behave aggressively and out of a job if they don't. Title VIl lifts women out of this bind." Id. at 25I. For the Price Waterhouse plurality, does Title VIl merely proscribe judgments on the basis of formal-sex? Or, does the statute proscribe stereotyping, considered as the failure to recognize that the individual plaintiff might have an instrumentally valuable trait (aggressiveness) that most other members of her class lack? Or, does the statute instead proscribe a varient of sex-plus, the refusal to hire an aggressive woman for a job that requires aggressive behavior, so that failure to hire a part of the class is tantamount to a refusal to hire all of the class, the "intolerable and impermissible Catch-22" to which the plurality opinion refers? The Price Waterhouse opinion understands that the refusal to promote an aggressive woman represents a prescriptive judgment that plays an important role in sustaining sex discrimination, but it is never confident in explaining how or why this is so. This confusion is evident in the way that the opinion characterizes the case as presenting a problem of "mixed-motive" discrimination. See id. at 234-36 (identifying as illegitimate ground of decision overtly sex-based comments about plaintiff's "aggressiveness" and as "legitimate" ground of decision putatively gender-neutral judgments about deficiencies in plaintiff's "interpersonal skills" in dealing with staff members). 
and contextually, as repudiating the relevance claims of status-race talk; and, when understood in this way, the claim that "race has no social relevance" is, of course, rich with meaning. But to observe as much is to recognize that the meaning of formal-race discourse arises in an act of negation, as formal-race discourse repudiates the particular set of practices and justifications associated with status-race discourse..$^{82}$ Once antidiscrimination law prompts the removal of "whites-only" signs from institutions and practices, however, the claims of formal-race discourse begin to function somewhat strangely as a framework in which to evaluate the distributive justice of the practices that remain. This problem arises because of the usages of formal-race discourse itself. Formal-race discourse defines race in ways that are deeply at odds with the understandings of race that would seem to be relevant to evaluating the justice of our distributive practices.

Consider again how color blindness discourse understands the term "race"-as a group-categorical distinction that has no social relevance. In debates over the justice of our distributive practices, it might make symbolic or expressive sense to assert that race has no social relevance; but this claim about race, once disassociated from the historically-specific practices and rhetorics it originally sought to contest, is not a sensible way of talking about race if we mean to evaluate the justice, fairness, or distributive neutrality of particular practices that are alleged to discriminate on the basis of "race." To begin thinking about whether a particular practice might be just or fair with respect to matters of "race," it would seem that we would have to analyze "race" as it is manifested in a given society at a particular juncture of history: that is, to consider race as a social formation-like ethnicity and gender, arising out of the unequal distribution of socially salient traits across populations, or more dynamically, as a group-status relation arising out of the interaction of social structure and social meaning.

Yet as soon as we begin such a discussion, we will depart from the specialized assumptions about race on which formal-race talk is premised. Current scientific and social-scientific accounts of race do not treat race as a group-categorical distinction but instead conceptualize race in terms of group-salience-as arising out of the uneven incidence of genetic or

82. As we have seen, formal-race talk takes its normative orientation from a particular sociohistorical project-the disestablishment or alleviation of racial stratification-during a period when racial stratification was enforced by a particular set of practices (employing group-categorical distinctions) that were in turn rationalized by a particular set of justifications (asserting the social relevance of race). Standing alone, formal-race talk quite self-consciously offers no social account of race apart from the claim that race has no social, political, or moral relevance. But if we reflect on the semantic structure of this claim, we can see that its (highly specialized) social meaning arises in the negation of another set of claims about race. Differently put, the claim that race has no social, political, or moral relevance derives all of its social, political, and moral valence in the repudiation of the particular social, political, and moral account of race offered by status-race discourse (i.e., claims of "prejudice," "racism," or "White Supremacy"). 
phenotypic or social traits in a population; ${ }^{83}$ this is the approach to race reflected in historical-race and culture-race discourses. Further, historicalrace and culture-race discourses understand race as aggregations of socially relevant traits-that is, they conceptualize race as made of norms, understandings, cognitive and practical skills, material resources, life experiences, practices, activities, memories, concerns, commitments, fears, interests, desires, and identifications that are distributed in a society in group-salient patterns that persist with variable intensity over time. Some version of this approach to conceptualizing race as a social formation seems inevitable in debates over the justice of our distributive practices, however complexly we model the problem in institutional, dynamic, economic, or other terms. For if we want to identify particular social practices that are distributively just with respect to race, it would indeed seem that, whatever our view of distributive fairness, we would have to reason about race as it is socially instantiated, whether in historical or cultural terms.

By contrast, when antidiscrimination law reasons in terms of formalrace, the law defines discrimination with respect to a very specialized notion of race-race understood as a subgroup of the population marked by no traits of any social relevance. Once race is defined this way, any practice that can be characterized as rationally selecting for a socially relevant trait can be characterized as neutral with respect to race: that is, as

83. The Supreme Court intermittently analyzes race in this way, as do an increasing number of scholars. See, e.g., Saint Francis College v. Al-Khazraji, 481 U.S. 604, 609 n.4 (1987) (discussing biological and anthropological studies supporting view that "racial classifications are for the most part sociopolitical, rather than biological in nature"; noting that literature contends that "genetically homogeneous populations do not exist and traits are not discontinuous between populations; therefore, a population can only be described in terms of relative frequencies of various traits [and] [c]lear-cut categories do not exist"); Anthony Appiah, The Uncompleted Argument: Du Bois and the Illusion of Race, in "RACE," WRITING, AND DIFFERENCE 21, 30-32 (Henry Louis Gates, Jr. ed., 1985) (discussing genetic studies demonstrating "extent to which members of . . . human populations we call raccs differ more from each other than they do from members of the same race"); lan F. Haney Lopez, The Social Construction of Race: Some Observations on Illusion, Fabrication, and Choice, 29 HARV. C.R.-C.L. L. REv. 1, 10-16 (1994) (same); id. at 7 (describing race as "a vast group of people loosely bound together by historically contingent, socially significant elements of their morphology and/or ancestry, ... a sui generis social phenomenon in which contested systems of meaning serve as the connections between physical features, races, and personal characteristics").

Genetic and cultural accounts of race can be expressed in homologous terms, as arising out of the distribution of traits in a population. On this view, cultures are populations marked by distributions of relatively similar norms and understandings. $C f$. BALKJN, CULTURAL SofTWARE, supra note 56, at 49$50,53,90-97$ (observing that cultures and subcultures are distributions of relatively similar shared understandings and habits). These traits, norms, and understandings are, of course, embedded in social relations and social structures that play an important part in making them meaningful. Contemporary theorists emphasize the dynamic interplay of social structure and social meaning in constructing race. See also Haney Lopez, supra at 7 (asserting that race "is neither an essence nor an illusion, but rather an ongoing, contradictory, self-reinforcing process subject to the macro forces of social and political struggle and the micro effects of daily decisions"). See generally OMI \& WINANT, supra note 32 (rejecting the view that race has a biological foundation and the view that it is merely a social "illusion" or cognitive error; adopting "racial formation" approach that understands race as growing out of interaction of "both social structure and cultural representation"). 
differienting on the basis of some trait other than race itself. But, of course, the "race" with respect to which the practice is said to be neutral is something of a legal fiction, in the sense that this usage of the term "race" arises out of special mode of talking about race (formal-race) that insists that race is a group-categorical distinction that has no social relevance.

Our analysis of Griggs demonstrated just how limited color blindness talk is as a framework for reasoning about the justice of distributive practices in matters of race. In Griggs, as we saw, the Court relinquished the premises of formal-race discourse in order to reason about race as it is socially embodied in history. From this sociohistorical standpoint, the Court recognized that race is a site of unequal distribution of socially valuable (i.e., relevant) educational resources. Once the Court began to reason about race and education this way, it tacitly acknowledged that making judgments about the socially relevant traits of "individuals" involves making judgments within, not without, the social field of race. ${ }^{84}$ Yet, precisely as Griggs verged on recognizing this fact, the opinion repressed the recognition by urgently reinvoking the premises of formal-race discourse and asserting that hiring criteria which select for traits that are relevant to the achievement of business purposes are distributively neutral with respect to race. ${ }^{85}$

Thus, as our analysis of Griggs demonstrates, the vice (or virtue) of color blindness discourse is that it conceals the distributive consequences of group-salient practices in a semantic code that defines instrumentally rational utterances as race-neutral. As antidiscrimination law tells the story, we never even have to face the question of reconciling conflicts between equality and efficiency goals, because formal-race discourse draws upon concepts of instrumental rationality as a framework im which to define distributive justice in matters of race. Since Tussman and tenBroek began reasoning about race discrimination as a breach of instrumental rationality ${ }^{86}$ an approach that was in turn embedded in the foundations of strict scrutiny doctrine ${ }^{87}$ - the law has defined practices that can be characterized as selecting for traits that are instrumentally related to the achievement of legitimate social ends as practices that do not discriminate on the basis of race. In so doing, antidiscrimination law has defined distributive fairness in matters of race in terms of a specialized concept of race-formal-race-

84. This would seem to follow, so long as we can identify no relevant distinction between the traits that are said to constitute individuals (as they appear in the particular bundles we call persons) and the traits that are said to constitute groups (as they appear in the particular distributions that give groups their distinguishable social "identities").

85. As Griggs triumphantly concludes, "Congress has not commanded that the less qualified be preferred over the better qualified simply because of minority origins. Far from disparaging job qualifications as such, Congress has made such qualifications the controlling factor, so that race, religion, nationality, and sex become irrelevant." Griggs v. Duke Power Co., 401 U.S. 424, 436 (1971).

86. See supra note 53 and accompanying text.

87. See id. (discussing legal-process approaches to antidiscrimination law). 
that, by definition, has no connection to those social features of race (whether historical or cultural) that might bear on the justice of our distributive practices. ${ }^{88}$

Yet the system of characterization employed by antidiscrimination law has been used by courts to designate a wide variety of race-salient practices as race-based, even when such practices are not identified by a sign reading "whites only." It has also been employed by courts to characterize a wide-variety of race-salient practices as race-neutral, even when such practices are justified in the semantic code that has grown up in our civil rights culture to enable whites who understand themselves to be raceegalitarians to continue arguing about race relations without speaking in race-categorical terms. ${ }^{89}$ What exactly is driving these results?

Once "whites-only" signs are removed, the power of color blindness discourse to disrupt or to rationalize social stratification at any given moment in history seems to depend, not on some Archimedean point of race-neutrality that the discourse of color blindness identifies, but rather on independent views about the nature of race held by those who wield the discourse. Differently put, those who embrace color blindness norms also hold beliefs about the nature of race as a social formation, and, in various doctrinal contexts, those concurrent convictions about the social nature of race play an important role in determining whether, and to what extent, claims about color blindness tend to undermine or legitimate social stratification.

If one assumes that, absent discrimination, members of different racial groups are relatively similar in their interests and abilities, then one would expect to find a relatively similar distribution of different groups throughout various fields of social endeavor; if, on the contrary, one assumes that there are significant and lasting differences amongst such groups, then one would expect to find an unequal distribution of the groups throughout the society. During the first decades of the Second Reconstruction, it was often assumed that differences in the social distribution of racial groups were

88. When discrimination and neutrality are defined with respect to formal race, this highly abstract account of race will efface structural inequality in baselines and norms that shape meritocratic competition. Formal-race discourse does not register (1) inequality in the resources with which members of different groups can compete or (2) the group-salience of traits deemed relevant to success in any given social undertaking, a form of bias often attributable to the group-affiliation of those who originally defined how a task was to be performed, or to status-marking of the traits themselves (i.e., leadership requires "aggression" rather than "sensitivity," "initiative" rather than "responsiveness").

89. Cf. Siegel, Equal Protection, supra note 20, at $1135-48$ (demonstrating how prevailing definitions of discriminatory purpose insulate practices that are highly race- and gender-salient from legal challenge, with special attention to questions of crack cocaine and domestic violence); see also supra notes 32-33 and accompanying text (discussing how linguistically competent social actors are aware of the differences between group-categorical and group-salient distinctions and can manipulate them when discussing matters implicating race and gender relations). 
largely attributable to the effects of present or past discrimination..$^{90}$ Since the 1970s, however, a growing body of scholars has drawn upon ethnicity theory to attempt to explain social stratification as a product of group cultural dynamics rather than "discrimination." As Nathan Glazer and Daniel Moynihan explained in their introduction to a book on ethnicity in 1975: "[E]thnic groups bring different norms to bear on common circumstances with consequent different levels of success-hence group differences in status." This social-scientific examination of the traits that might account for the success and status of ethnic (i.e., "outsider") groups offered a new way of talking about the relation of group difference and group stratification-one that self-consciously distinguished itself from the traditions of status-race talk and explained differences in the social position of groups as arising out of group-salient distributions of traits in a population; consequently, this approach allowed for discussion of group difference and group status on terms that could be reconciled with the central tenets of formal-race talk. Indeed, the race-as-ethnicity story did more than offer a way of talking about group difference and group status that was consistent with the central tenets of color blindness discourse; it coupled the story about individualism told by formal-race talk with culturally potent narratives about the immigrant's struggle from rags-to-riches that played an important role in redefining the sociopolitical salience of color blindness discourse in politics and law.

Since the 1970 s, assumptions about race-as-ethnicity have increasingly structured arguments about the moral grounds for and proper application of antidiscrimmation law in popular, academic, and ultimately, legal fora. ${ }^{92}$ Consistent with their origins in a theory of social stratification, these

90. For an illustration of how the interpretive presumptions of antidiscrimination law used concepts of discrimination to explain disparities in racial representation, see, for example, International Brotherhood of Teamsters v. United States, 431 U.S. 324 (1977). In the case the Court stated that statistics can be an important source of proof in employment discrimination cases, since

absent explanation, it is ordinarily to be expected that nondiscriminatory hiring practices will in time result in a work force more or less representative of the racial and ethnic composition of the population in the community from which employees are hired. Evidence of long lasting and gross disparity between the composition of a work force and that of the general population thus may be signficant even though ... Title VII imposes no requirement that a work force mirror the general population.

Id. at 340 n.20; see also Vicki Schultz, Telling Stories About Women and Work: Judicial Interpretations of Sex Segregation in the Workplace in Title VII Cases Raising the Lack of Interest Argument, 103 HaRv. L. REv. 1750, 1771-75 (1990) (discussing race discrimination cases decided between 1967-71 that explained the dearth of minority applicants for particular jobs in terms of a "futility" doctrine which interpreted the employment preferences of minority applicants in light of the exogenous-and racially discriminatory-norms and practices that might have shaped them).

91. Nathan Glazer \& Daniel P. Moynihan, Introduction, $i$ n ETHNiCITY: TheoRY AND EXPERIENCE 17 (Nathan Glazer \& Daniel P. Moynihan eds., 1975), quoted in OM1 \& IV1NANT, supra note 32 , at 31 .

92. It would be a much longer story to trace how this mode of reasoning about race infiltrates and begins to reshape antidiscrimination law during the 1970 s and 1980 s, affecting interpretive presumptions concerning the ways one proves an individual disparate treatment claim and a pattern or 
race-as-ethnicity arguments most frequently view race as manifesting itself in socially relevant, group-salient differences-a narrative frequently invoked to explain persisting social stratification in a society committed to meritocratic, individualist, and color-blind principles of distribution..$^{93}$

practice claim, see, e.g., Hazelwood Sch. Dist. v. United States, 433 U.S. 299 (1977), as well as the disparate impact claim, see Watson v. Fort Worth Bank \& Trust, 487 U.S. 977 (1988); Wards Cove Packing Co. v. Atonio, 490 U.S. 642 (1989), and the debate over racial quotas that culminated in the Civil Rights Act of 1991.

The race-as-ethnicity story also played a rich and complicated role in the retrenchment of affirmative action law, starting with Justice Powell's compromise reformulation of educational affirmative action as serving "diversity" rather than remedial ends in Bakke, 438 U.S. 265 (1978). See Siegel, Colorblind Constitutionalism, supra note 20, at 40-41. "Diversity" supplied a socially compelling rhetoric for educational affirmative action precisely because the race-as-culture concept appealed to those who wanted to affirm racial identity as something other than the accretion of historical injustice - as well as those, such as Justice Powell, who wanted to resist demands for racial redistribution justified by historical-race discourse, or to dilute the authority of such collective-memory narratives by surrounding them with competing historical narratives of difference and disadvantage. See id.; see also Siegel, Collective Memory, supra note 20, at 136-37 (noting that Justice Powell's claim that "we are a Nation of minorities" repudiates collective responsibility for racial stratification "by deconstructing the category of white persons understood as decendants of slave-owners"). Soon thereafter, the race-as-ethnicity narrative began to play an important role in affirmative action law outside the educational context, when the Cour invoked culture-race discourse as a reason for intensifying the evidentiary showing that state actors would have to make in order to demonstrate they were entitled to adopt an affirmative action program for purposes of remedying past discrimination. See Siegel, Colorblind Constitutionalism, supra note 20, at $43-46$ (discussing cases such as City of Richmond v. J.A. Croson Co., 488 U.S. 469 (1989)).

Finally, it bears noting that during the 1980 s, these same currents were working themselves out in matters of sex discrimination law as well, most prominently in the debate provoked by the Sears case and "choice" or difference-based justifications for gender disparities in the work force. See EEOC v. Sears, Roebuck \& Co., 839 F.2d 302 (7th Cir. 1988). See generally Schultz, supra note 92 (discussing lack-of-interest arguments in sex discrimination cases).

93. See, e.g., Nathan Glazer, Affirmative Discrimination: Ethnic INequality and Public Policy 62-63 (1975) (arguing that antidiscrimination law erroneously assumes that, absent discrimination, there would be random distribution of women and minorities in all jobs, when the distribution of jobs among minority groups is best explained by differences in educational qualifications, regional variables, and difficult to quantify factors "such as taste or, if you will, culture"); Abram, supra note 70, at 1315-16 ("Because groups-black, white, Hispanic, male, and female-do not necessarily have the same distribution of, among other characteristics, skills, interest, motivation, and age, a fair shake system may not produce proportional representation across occupations and professions, and certainly not at any given time. This uneven distribution, however, is not necessarily the result of discrimination. Thomas Sowell has shown through comparative studies of ethric group performance that discrimination alone cannot explain these ethnic groups' varying levels of achievement.").

In a recent attack on the Civil Rights Act of 1964, Charles Murray offered an instance of this equality-of-opportunity/equality-of-results argument that is particularly transparent in its assumptions about the "real" nature of race and gender differences:

At any moment in history a completely fair system for treating individuals will produce different outcomes for different groups, because groups are hardly ever equally represented in the qualities that go into decisions about whom to hire, admit to law school, put in jail, or live next door to .... [A] system that ... judg[ed] each case perfectly on its merits [] would produce drastically different proportions of men and women hired by police forces, blacks and whites put in jail, or Jews and gentiles admitted to elite law schools.

Charles Murray, What it Means to Be a Libertarian: A Personal Interpretation 85-86 (1997). 
Infused with this specially coded narrative about race-as-ethnicity-a narrative that would seem to be interested in cultural accounts of race only insofar as the "culture"-concept provides an explanation, and justification, for social stratification-antidiscrimination law can become a powerful tool for rationalizing social inequality. For once formal-race talk is coupled with this highly specialized form of culture-race talk, the particular version of color blindness discourse that results will begin to interpret existing distributions as evidence of the outcomes that result when "individuals" and the groups to which they belong are given "equality of opportunity." Discrepancies in the rates at which different groups participate in various fields of social endeavor no longer seem to be the product of present or past discrimination; ${ }^{94}$ instead discrepancies in the rates at which different groups participate in various fields of social endeavor will appear as evidence of the differing distribution of group-salient traits that mark and define racial (or ethnic or gender) groups as culturally distinct groups. From this same standpoint, any attempt to vary the rate at which different groups participate in various fields of social endeavor will appear as a breach of distributive neutrality and an inefficient and unjust form of "social engineering." 95

Yet, as should be plain by now, the only way that such accounts can demonstrate that existing discrepancies in group participation result from the workings of equality of opportunity (rather than discrimination) is by asserting beliefs about race-as-ethnicity-that is, by describing race as manifested in the unequal distribution of socially relevant traits throughout the population. ${ }^{96}$ As Charles Murray succinctly puts it:

At any given moment in history a completely fair system for treating individuals will produce different outcomes for different groups, because groups are hardly ever equally represented in the

The Supreme Court would seem to have adopted some (presumably more temperate) version of this social hypothesis to discredit the presumption that the discrepant representation of minority groups is likely attributable to discrimination, and disparages assumptions about "proportioual representation" in order to justify, inter alia, constitutional restrictions on affirmative action. See Siegel, Colorblind Constitutionalism, supra note 20, at 57-61 (analyzing racial commitments of color-blind constitutionalism). See generally id. at 54 ("A story about competition among groups with different genetic and cultural endowments explains, and justifies, relations of racial status; a story about maintaining appropriate distinctions between public and private spheres explains, and justifies, legal rules that preserve relations of racial status.").

94. Cf. supra note 90 and accompanying text (discussing presumptions of race discrimination jurisprudence during the 1960 s and 1970s).

95. See supra note 93 (discussing interpretive presumptions of culture-race discourse as elaborated during the last several decades).

96. This observation addresses the debate as it unfolds in the political arena, where too often "discrimination" and "culture" are treated as distinct and opposing, rather than interlocking and mutually constitutive, social processes that might cause discrepancies in the rates at which members of different groups participate in various fields of social endeavor. 
qualities that go into decisions about whom to hire, admit to law school, put in jail, or live next door to. . . ${ }^{97}$

In short, the claim that race neutrality is served by embracing principles that secure "equality of opportunity" rather than "equality of result" turns out to rest on independent social assumptions about the nature of race that flatly contradict the premises of color blindness discourse itself. Such arguments nicely demonstrate iny earlier point that formal-race discourse, standing alone, does not supply a basis in which we can cogently debate the justice of our distributive practices; to enter such a debate, one has to make certain claims about the nature of race as a social formation-that is, to begin to talk about race as it is manifested in a particular society at a particular juncture of history. This color blindness discourse cannot do, unless those employing formal-race talk overtly or covertly couple this mode of reasoning about race with modes of reasoning about race that are rooted in historical-race or cultural-race discourse.

To summarize the argument as I have developed it thus far, color blindness discourse in antidiscrimination law is a mode of characterizing social practices that specifies whether such practices distribute access to social goods in legitimate ways; it works both to discredit and to rationalize practices that maintain social stratification. Because color blindness discourse defines "discrimination on the basis of race" in highly specialized ways - as a practice of group-categorical differentiation that serves no instrumentally relevant end-color blindness discourse can both discredit and rationalize practices that perpetuate racial stratification.

Formal-race discourse originated in the effort to explain why practices that overtly segregated on the basis of race were instrumentally irrational and distributively unjust. Once antidiscrimination law used formal-race discourse to eliminate practices that overtly classified on the basis of race, the rhetoric of formal-race discourse took on a new life. Because formalrace discourse defines race as a group-categorical distinction having no social relevance, formal-race discourse can now be used to characterize as race-neutral any race-salient practice that can be described as instrumentally related to the achievement of a legitimate social end. But such practices are only neutral with respect to a highly restrictive definition of race-race understood as a form of group categorical distinction that has no social relevance. This highly formalized mode of characterizing practices conflates claims about the instrumental rationality of practices with claims about the distributive justice of practices; claims about the distributive justice of practices generated within this formal-race framework are unpersuasive precisely because race has been defined as a trait that has no social relevance-an understanding of race that would seem entirely

97. MURRAY, supra note 93 , at 85 . 
unsuited to deciding whether practices are distributively just with respect to race. As we examine the application of antidiscrimination law and the political debates it has engendered, it would appear that the power of color blindness discourse to disrupt or to rationalize social stratification does not flow from the ability of formal-race discourse to identify some ground of distributive neutrality in social practices but instead reflects assumptions about the nature of race as a social, historical, or cultural formation that are independent of - and in conflict with - the formal premises of color blindness discourse itself.

III

\section{"Preservation-Through-Transformation": Antidiscrimination and ANTISUbordination PRINCIPLES IN SOCIOHISTORICAL PERSPECTIVE}

To this point I have tried to show how the concept of stratification missing from Post's sociological account of the field enables us to make more sense of the trope of blindness at the heart of antidiscrimination law. In the preceding Part of my Response, I showed how color blindness discourse relates social structure and social meaning in such a way as to disrupt racial stratification and to rationalize it. In concluding my Response, I now want to give this argument temporal extension, to consider its implications given the ways that practices and meanings which sustain group inequality evolve as they are contested over time. I believe that a sociological approach that is attentive to stratification and the mutability of status-enforcing practices can teach us much about the changing sociopolitical salience of color blindness discourse over the course of the Second Reconstruction, and in so doing, shed new light on the debate between antidiscrimmation and antisubordination norms that currently divides academic and popular opinion about matters of race and sex equality.

As I take up these questions, I will be reflecting once again on what it means to do antidiscrimination law from a sociological standpoint, and so returning to the main challenge of Post's Lecture. First, and perhaps most significantly, I will argne that a sociological approach attentive to stratification and to the mutability of status-enforcing practices can in fact tell us more about the underlying purposes of antidiscrimination law than Post's Lecture suggests. When we consider how tropes of blindness have been deployed from a sociohistoric vantage point, we can see that a commitment to alleviating stratification is and has been central to the project of antidiscrimination law since the beginning of the Second Reconstruction. But, I argue, the very method of analysis that demonstrates the centrality of this normative commitment to the antidiscrimination project simultaneously reveals the limitations of meta-principles (such as "antidiscrimination" or "antisubordination") in guiding our critical practices. Thus, in the final analysis, I concur with Post that a sociological approach to the field 
constructively reframes many important normative questions, yet does so without rendering them amenable to resolution by application of general principles alone. I reject the legal-formalist assumption that abstract ("principled") reasoning alone can adduce the kinds of social groups towards which discrimination is directed or the kinds of social forms it assumes. However much such understandings may be informed by principle, they are forged in history, through social struggle, as various features of social stratification are contested over time.

To resume consideration of some of the larger methodological questions raised by Post's Lecture, I would like to begin this last Part of my Response as I intend to end it: by pausing to consider reflexively where we stand as we comment on the nature of antidiscrimination law. In his Lecture, Post characterizes the alternative perspective he offers on antidiscrimination law as "sociological;" at various points I have characterized my own style of analysis as "sociohistorical." Each of us is nevertheless doing "law"- -endeavoring to step outside doctrinal frameworks of analysis to make observations about the operations of law that we understand as deeply pertinent to the development of the law, and ultimately, to the formulation of doctrine itself. Indeed, it seems to me that this effort to break out of legal categories and apprehend the "real" and "actual" operations of law in society is a characteristic feature of legal reason, one familiar way in which members of a legal order contest its governing rules and norms. In such struggles, doctrine typically is denounced as overly, if not perniciously, formalistic, and legal decision makers are urged to take actual social practices and understandings into account in reshaping the law. This impulse may assume the form of a self-conscious jurisprudential movement, such as Legal Realism, or a call for interdisciplinarity within law, such as Sociological Jurisprudence or Law and Economics. Or, this impulse may manifest itself interstitially, as an appeal to common social understanding that appears in the course of ordinary legal argument. For example, many of the most famous rhetorical assaults on Jim Crow are appeals for legal doctrine to take account of what "[e]veryone knows" about the "real meaning" of segregation. ${ }^{98}$ Indeed, as we consider the rhetorical form of such interpretive conflicts, we can see eerie parallels between Justice Harlan's passionate challenge to legal formalism and

98. Plessy v. Ferguson, 163 U.S. 537, 557 (1896) (Harlan, J., dissenting); cf. Charles L. Black, Jr., The Lawfulness of the Segregation Decisions, 69 Y ALE L.J. 421, 424 (1960) (responding to the claim that segregation treats the races "'equally" with the suggestion that "we ought to exercise one of the sovereign prerogatives of philosophers-that of laughter"). In Brown, the Court avoided this kind of appeal to common social understanding by invoking social-seientific evidence about the harms of segregation in the opinion's predictably criticized "footnote 11." See Brown v. Board of Educ., 347 U.S. 483, 494 n.11 (1954). 
indignant protests about the meaning the Court has given "equal protection" today. ${ }^{99}$

Since the delegitimation of Jim Crow, appeals for antidiscrimination law to take into account social structure and social meaning typically occur within two areas of doctrine: in debates about the legality of "group-conscious" remedies that differentiate among individuals on the basis of group membership, and in debates about the legality of "facially neutral" practices that differentially burden groups without formally differentiating among their members. Doctrinal debate occurred in these areas because, as my analysis of Griggs shows, by the 1970s civil rights law had precipitated a shift in the rule structure and justificatory rhetoric of the practices that enforced the differential social status of racial groups. ${ }^{110}$ With the enforcement of civil rights law during the 1950s and 1960s, those whites interested in preserving racial stratification began to abandon the use of overt group-categorical distinctions, more or less at the same time as those interested in using civil rights law to alleviate racial stratification began to employ practices incorporating group-categorical racial distinctions. ${ }^{101}$ Under these circumstances, the doctrinal injunction against discrimination-with its account of blindness understood as a prohibition on group-categorical race and sex distinctions-seemed to point equality law in directions at odds with the intuitions of many civil rights advocates interested in ameliorating the persisting inequality of traditionally disempowered groups.

In 1976, Owen Fiss engaged these debates about the legality of "benign" racial distinctions and facially neutral practices in an influential article that appeared in Philosophy \& Public Affairs entitled Groups and the Equal Protection Clause. ${ }^{102} \mathrm{He}$ opened his argument with an appeal for law to free itself from the constraints of antidiscrimination doctrine and renew itself by once again examining the social relationships it was endeavoring to shape. As Fiss defined his project:

99. Consider Justice Harlan's demand in Plessy for the Court to take account of what "[e]veryone knows" about the "real meaning" of segregation, 163 U.S. at 557, and the challenge to legal formalism that drives Justice Stevens' dissent in Adarand Constructors v. Pena, 515 U.S. 200 (1995), in which Justice Stevens argued,

The Court's explanation for treating dissimilar race-based decisions as though they were equally objectionable is a supposed inability to differentiate between 'invidious' and 'benign' discrimination. ... But the term 'affirmative action' is common and well understood. Its presence in everyday parlance shows that people understand the difference between good intentions and bad.

Id. at 245 (Stevens, J., dissenting); see also id. ("The consistency that the Court espouses would disregard the difference between a 'No Trespassing' sign and a welcome mat.... An interest in 'consistency' does not justify treating differences as though they were similarities.").

100. Cf. supra text accompanying notes $25-27$ (discussing the preservation-throughtransformation dynamic).

101. See Siegel, Equal Protection, supra note 20, at 1141-44.

102. Owen M. Fiss, Groups and the Equal Protection Clause, 5 PHIL. \& PuB. AfF. 107 (1976). 
I want to suggest that the antidiscrimination principle embodies a very limited conception of equality... [and] to outline another mediating principle - the group-disadvantaging principle-one that has as good, if not better, claim to represent the ideal of equality, one that takes a fuller account of social reality, and one that more clearly focuses the issues that must be decided in equal protection cases. ${ }^{103}$

The "group-disadvantaging principle" that Fiss proposed in 1976 is often referred to as an "antisubordination principle," an "antisubjugation principle," or an "anticaste principle," and especially as elaborated by Catharine MacKinnon, ${ }^{104}$ Derrick Bell, Laurence Tribe, Charles Lawrence, Randall Kennedy, Ruth Colker, Cass Sunstein, Kenneth Karst, and many others, has played a central role in the equality literature, ${ }^{1,55}$ particularly in debates over affirmative action and doctrines concerning discriminatory purpose and disparate impact. ${ }^{106}$

I was fortunate to study equality law with Owen Fiss, as did Robert Post before me, and my approach to equality law has, from the outset, been profoundly shaped by the antisubordination literature: by the quest to understand antidiscrimination law in light of social structure and social struggle, as involving problems in group inequality. Yet I was never drawn to the project of philosophically elaborating an antisubordination principle as such. Perhaps because of our common training in American literature and history, I share with Robert Post a skepticism that law can be fruitfully articulated in principles that can be abstracted from the concrete social practices law aspires to shape ${ }^{107} \mathrm{It}$ is for this reason that I have attempted to analyze questions of gender and race inequality in a "thick"

103. Id. at 108.

104. Mackinnon was the first to give an extended, particularized, and critically provocative explication of the antisubordination approach in her influential analysis of sexual harassment. See Catharine A. Mackinnon, Sexual Harassment of Working Women (1979) [hereinafter MacKinnon, SEXual HaRAsSment]; her subscquent elaboration of the theoretical framework of this path-breaking work has been equally influential in the antidiscrimination literature. See Catharine A. MacKinnon, Difference and Dominance: On Sex Discrinination, in FEMINISM UNMODIFIED 32 (1987).

105. See, e.g., LAUREnCe H. TRibe, American Constitutional LaW \$ 16-21, at 1514-21 (2d ed. 1988); Ruth Colker, Anti-Subordination Above All: Sex, Race, and Equal Protection, 61 N.Y.U. L. REv. 1003 (1986); Kenneth L. Karst. The Supreme Court, 1976 Tern-Foreword: Equal Citizenship Under the Fourteenth Amendment, 91 HARv. L. REv. 1 (1977); Randall Kennedy, Persuasion and Distrust: A Comment on the Affirmative Action Debate, 99 HARv. L. REv. 1327 (1986); Charles R. Lawrence III, The Id, the Ego, and Equal Protection: Reckoning with Unconscious Racism, 39 STAN. L. REv. 317 (1987); Sunstein, supra note 70, at 2410.

106. See, e.g., Siegel, Reasoning from the Body, supra note 20, at 369 n.426 (citing commentators who have employed antisubordination values "to distinguish between benign and invidious race- and sex-based state action, as well as to criticize doctrines requiring a showing of discriminatory purpose to challenge facially neutral state action").

107. For one account of Post's views on these matters, see Robert Post, Recuperating First Amendment Doctrine, 47 StaN. L. Rev. 1249, 1272-73 (1995) (arguing that "law ... does not deal with values as merely abstract ideas or principles;" instead, "all legal values are rooted in the experiences associated with local and specific kinds of social practices"). 
sociohistorical framework, examining the institutions, practices, stories, and meanings through which group stratification has been maintained, with special attention to the ways in which such institutions, practices, stories, and meanings have evolved through periods of social conflict. Indeed, one reason that $I$ have engaged in this project of thick description is to show how the antisubordination principle can be understood as an appropriate expression of antidiscrimination commitments in sociohistorical, rather than philosophical, terms. ${ }^{108}$

My work illustrates how struggles over group inequality can transform the rules and reasons by which social stratification is enforced and justified. This dynamic, which I call "preservation through transformation," ${ }^{\text {"1k9 }}$ suggests why the debate between antidiscrimination and antisubordination principles transpired during the 1970s. As civil rights advocates challenged the conventional practices and rationales supporting race and gender inequality, they precipitated a shift in the rule structure and justificatory rhetoric of these status regimes. In time, an antidiscrimination principle that had been elaborated with respect to the statusenforcing practices and rationales of the early twentieth century became illsuited for challenging the kinds of status-enforcing practices and rationales that emerged in their wake. ${ }^{110}$ It is in this context that we can understand Fiss's call in 1976 for a new "mediating" principle through which to interpret the Equal Protection Clause.

Considered from this sociohistorical vantage point, we can understand Fiss as expressing the normative commitments of the "Second Reconstruction" in rhetorical terms that might enable continued critical engagement with the world the civil rights movement brought into being. That world was one in which-thanks to color blindness discourse-many of the traditional practices and rationales supporting race and gender inequality were discredited; yet it was also a world in which-again, thanks to color blindness discourse-stratification by race and gender persisted across social sectors, often enforced in new ways and rationalized in new rhetorical terms. As Griggs illustrates, in this world, social stratification was commonly sustained through "facially neutral" practices, rather than group-based classifications, while group-based classifications were more coinmonly employed to alleviate social stratification than to entrench it. ${ }^{11}$ Fiss's "group-disadvantaging principle" thus began the work of translating

108. See generally Siegel, Equal Protection, supra note 20 (analyzing contemporary equal protection doctrines in long-term historical perspective); of. Siegel, Colorblind Constitutionalism, supra note 20 , at $57-61$.

109. Siegel, Rule of Love, supra note 20, at 2175-88 (describing dynamic of preservation-throughtransformation).

110. Cf. id. at 2188-96 (discussing gender cases); Siegel, Equal Protection, supra note 20, at 1141-48 (discussing race cases).

111. See id. 
the status-disestablishing commitments of the Second Reconstruction into rhetorical terms better adapted to challenging the status-enforcing practices of the civil rights era. In this universe, the discourse of antisubordination identified and critically illuminated the social practices supporting race and gender stratification in ways that, Griggs notwithstanding, the discourse of antidiscrimination and color blindness no longer could. ${ }^{112}$

On this account, then, Fiss and those who followed him sought a new language in which to describe the assault on racial stratification already initiated during the Second Reconstruction in the language of color blindness itself. If I am correct in this account, then it would appear that sociohistorical analysis enables us to say considerably more about the purposes of equality law than Post has. Throughout his Lecture, Post suggests that a sociological understanding of antidiscrimination law would have us reshape race and gender conventions so as to promote the purposes of the law. But he never gives any hint as to what those purposes might be. By contrast, on my account, the purpose of antidiscrimination law is and has been to ameliorate certain forms of racial group stratification. At the height of the civil rights movement, the discourse of antidiscrimination and color blindness constrained certain practices used to enforce racial segregation and to this extent served to alleviate group inequality. In other words, at the beginning of the Second Reconstruction, the discourse of "antidiscrimination" promoted what we might now understand as "antisubordination" ends. Clarifying this much about the moving commitments of the Second Reconstruction seems to me of absolutely crucial consequence, given the very different racial views and commitments of those who now claim Martin Luther King's legacy. ${ }^{13}$

Of course, in King's era, application of antidiscrimination principles only partly disestablished group stratification; nor is it clear that many of the white Americans who applied such principles ever aspired to more. ${ }^{114}$ No doubt in this social struggle, as in so many others, Americans differed

112. Cf. Siegel, Colorblind Constitutionalism, supra note 20, at 56 (arguing that the sociopolitical salience of color blindness discourse varies with the historical context in which it is invoked). Color blindness discourse was rhetorically designed to delegitimate the group-cafegorical classifications of status-race discourse as status-race discourse stood at the beginning of the Second Reconstruction. As 1 have demonstrated, see supra text accompanying notes $65-69$, it protected persons from no other form of group-based categorization, as it entitled persons to be treated as "individuals" with respect to their formal-race only. So, given particular social practices to which it was responsive, color blindness discourse ameliorated racial group stratification; that is, it worked to alleviate the subordination of African Americans as a group.

113. For illustrations of the ways that opponents of affirmative action invoke the mantle of the civil rights movement of the 1950s and 1960s, see Seigel, Rule of Love, supra note 20, at 2185 n.244. For an analysis of the social vision and normative understandings informing equality rhetoric in debates over the Civil Rights Act of 1964, see Drew Hansen, Civil Rights and the Making of the American Idcal, 1954-1964 (unpublished manuscript, on file with author).

I14. See, e.g., Siegel, Colorblind Constitutionalism, supra note 20, at 57-61; Siegel, Eyual Protection, supra note 20, at 1142-43. 
in their understanding of the kind of changes it would take to realize the ideal of equality in social practice, and just as importantly, they differed in the degree to which they imagined that a world of race and gender equality would nonetheless remain race- and gender-stratified. ${ }^{115}$

Indeed, if we consider the question at this level of specificity, I agree with Post that a sociological approach still requires close and context-based analysis of the purposes of antidiscrimination law before it can be translated into legal doctrine. To see why, let us turn from the problems of positive to normative analysis, that is, from historical reconstruction to present prescription. Suppose we embrace an antisubordination priniciple. On what grounds do we decide which practices inflict dignitary harm? Any expression of sexuality in the workplace? If not, which expressions of sexuality, and why? How much differentiation on the basis of race or gender should survive in a race- and gender-equal world? And in which social contexts? In the family setting? In matters of erotic attraction? In the world of work? Politics? War? Even if we say that antidiscrimination law has as its purpose the disestablishment of entrenched forms of group inequality, or the amelioration of social stratification, or the general end of eliminating the unjust subordination of traditionally disempowered groups, there obviously remains ample ground for disagreement in a variety of social contexts about the particular ends we are seeking, the best means of achieving them, and finally, the kinds of group life that amelioration of social stratification will support. In short, the very method of analysis that demonstrates the centrality of antistratification concerns to the antidiscrimination project simultaneously reveals the limitations of "meta-principles," such as "antidiscrimination" or "antisubordination," in guiding our critical practices.

Once we understand equality and discrimination as problems in group stratification produced and rationalized by an ever-changing array of social practices and meanings, the question of our ends becomes far more complicated to articulate. As I have explored with respect to nineteenth-century conflicts over women's rights, attempts to imagine status-equality inevitably draw upon the status values of the very social order they aspire to disestablish. ${ }^{116}$ But the practices and meanings constituting the contested

115. This is exactly the problem we confront if we want to give any more precise and positive account of the heterogeneous commitments of civil rights advocates during the 1950s and 1960s. This was an era in which advocates spoke a language of blindness and individualism that worked to alleviate racial group stratification but that may have obscured, possibly from the advocates themselves, divergent visions of the kind of social world that tropes of color blindness might bring into being.

116. See Siegel, Home as Work, supra note 20, at 1131-35 (exploring how the joint property claim advanced by the nineteenth-century woman's rights movement transvalued gender conventions, drawing upon aspects of separate spheres discourse even as it was contesting it); id. at 1198-1205 (demonstrating how the movement's new conception of economic equality-avoiding domestic labor in favor of wage work outside the home-internalized status norms about work rooted in relations of gender, race, and class inequality). 
status order are always in flux, and so inevitably will be emancipatory efforts to imagine and express status-equality. Hence, during the 1970 s we witnessed a revolt against color blindness talk as an "assimilationist" rhetoric that tacitly encoded white privilege, and a corresponding effort to embrace "diversity" talk and to affirm the dignity of subordinated groups by contesting directly the traditional status-valuation of their social and cultnral traits. Race-that is, membership in a subordinated racial groupwas no longer something that had to be politely overlooked, but instead emerged as a social fact about which members of subordinated groups could express pride. Second-wave feminism began in this blindness tradition as well, with equality initially expressed in terms of the flight from motherhood, and then slowly reformulated into a demand for enhanced valuation of the institution, values, and work of nurturance, a dignitary claim that was almost immediately interrogated as a suspect form of "essentialism." 117 The movement for gay pride has similarly reappropriated and transvalued identity discourses and practices once only contemptuously referred to by the epithet "queer."

In short, discourses about subordination and equality set up a rhetorical framework in which we are continuously arguing about the ways human dignity is expressed in a given social order. The abstract language in which we express our principles or purposes can only point us to a question whose concrete resolution has to be fought out in the field of social life, with respect to a variety of different structures and meanings. It seems to me uncontrovertable that at any given moment of history, members of a society will experience many questions of status inequality, such as slavery or lynching, as relatively uncontroversial. Yet there are bound to be others about which there is deep social dissensus, such as "date rape," "meritocratic standards," or the ways we value child care. These

Of course, the tendency of emancipatory discourses to imagine equality in ways that tacitly incorporate the status values of the culture they are criticizing has been the subject of much recent commentary in the critical race literature. See, e.g., Angela Harris, Race and Essentialism in Feninist Legal Theory, 42 Stan. L. Rev. 581 (1990); see also Wendy Brown, States of INJURy: Power AND FREEDOM IN LATE MODERNITY (1995) (examining how resistance discourses and oppositional projects can incorporate discourses and values of the world they mean to subvert). Those who would employ an emancipatory discourse always must be interrogating that discourse in an attempt to ascertain whether its vision of equality rests on the value systems of an unjust status hierarchy. In particular, members of subordinated groups who may simultaneously occupy positions of privilege in other status orders must be vigilant in avoiding what I call "positional bias," or expressions of dignitary harms or movement goals that reflect the social experience and concerns of the subordinated group's more socially privileged members. "Essentialism" arising out of this kind of positional bias is in all likelihood unavoidable, and just as inevitably will and should be challenged with the ongoing contestation of social hierarchy. But the kind of essentialism I call "reification"-treating historically or circumstantially contingent aspects of group experience as relevant to the articulation of equality goals-seems to be an inevitable, and even necessary, part of the emancipatory project, so long as generalizations about the socially specific circumstances and traits of the subordinated group are treated as contingent and revisable. See Siegel, Home as Work, supra note 20, at 1211-17.

117. See id. 
controverted questions about the justice of our social practices set up a normative struggle about which there may or may not ever emerge wideranging social consensus. In short, there are many unanswered questions nested in the general commitment to ameliorate unjust forms of groupbased stratification or subordination, perhaps as many unanswered questions as are nested in the commitment to color blindness. Posing these questions in more concrete sociohistorical terms can fruitfully inform debate and focus dispute about them without necessarily resolving the matters in issue.

This is no doubt why Post suggests that the ends of judicial accountability and doctrinal coherence would be served by adoption of a sociological approach to the field. ${ }^{118}$ As my own work suggests, I am simultaneously compelled by such claims and yet despairing of them. Fundamental questions concerning the distribution of dignitary and material goods are at stake in disputes over antidiscrimination law. For just this reason the capacity of a sociohistorical or sociological approach to clarify positive and normative dimensions of the equality question may, in certain contexts, prove to be a liability as well as a virtue. For example, even if the "dominant approach" masks the actual operations of antidiscrimination law, judges and other legal decision makers may not necessarily wish to unmask them. The antidiscrimination narrative is, after all, a story told by members of relatively privileged groups explaining why they are prepared voluntarily to divest themselves of some of their status privileges. In a variety of circumstances, legal decision makers may not in fact wish to understand, acknowledge, or address the social dynamics that sustain the inequality of groups. ${ }^{119}$

Implicit in the sociological approach is a second potential liability. As we have seen, when considered from a sociological standpoint, the disestablishment of group inequality is a messy affair. Once we abandon tropes of transcendence and understand that we are aspiring to destabilize the social salience of race and gender without eradicating it, it is not always clear what equality looks like or how we get there. Such ambiguities are at the heart of recent disputes over sexual harassment law and pornography. The antidiscrimination literature now contains much discussion of subordination, but less frequently acknowledges the kinds of controversies that may arise in determining how particular practices "subordinate,"

118. See Post, supra note 1 , at $30-40$.

119. I espouse no simple determinism here, but observe only the uncontroversial: Social interest and social position can play a role in predisposing decision makers, advocates, and scholars to certain views about the appropriate ends of law. Cf. Siegel, Rule of Love, supra note 20, at 2180-81 (discussing how judges can interpret law "in good faith" while at the same time interpreting law in ways that reflect "selective sympathy and indifference" to certain social groups; observing that "[s]ometimes ... critical oblivion is bliss, especially when it is interest-convergent"). 
or why they do so. ${ }^{120}$ To avoid the complex and the contestable, both judges and advocates may shy away from discussing the kinds of interpretive and predictive judgments that support claims about equality and discrimination, sociologically conceived. In short, in our political culture, there are distinct advantages to maintaining the dominant conception. What tropes of blindness may lack in descriptive accuracy, they more than compensate for in familiar and uncontroversial rhetorical force.

Still, there is everything to be gained from wrestling with such large questions from a more particularized sociological standpoint, so long as we do so in full awareness of the positive and normative conflicts we are bound to encounter along the way. For it is in the crucible of contests such as these-high-stakes struggles at the intersection of social value and social practice - that a society continually revises its understanding of unjust status hierarchies and consequently opens its imaginative horizons to new forms of social ordering. So it is that this society has struggled, from generation to generation in times past, to reinvent itself in the more perfect image of its commitment to freedom and equality. And so it is that future generations of Americans will no doubt do so again.

120. Catharine MacKinnon first elaborated an antisubordination framework in the course of demonstrating how sexual harassment was sex discrimination, and her booklength analysis of a subordinating practice remains a model in the field. See MacKInNon, SEXUAL. HARAssment, supra note 104, at 117 (arguing that courts should evaluate contested practices with a view to determining "whether the policy or practice in question integrally contributes to the maintenance of an underclass or a deprived position because of gender status" and supplying detailed account of how sexual harassment does so). As Mackinnon continued to explore how relations of subordination are enacted in different forms of heterosexual sexual practice, her work generated increasing controversy. See, e.g., PLEASURE ANd DANGer: Exploring Female Sexuality (Carole S. Vance ed., 1984); Kathryn Abrams, Sex Wars Redux: Agency and Coercion in Feminist Legal Theory, 95 Couum. L Rev. 304, 329-46 (1995); Harris, supra note 116, at 598-601; Robin L. West, The Difference in Women's Hedonic Lives: $A$ Phenomenological Critique of Feminist Legal Theory, 3 Wis. WoMEN's L.J. 81 (1987). MacKinnon surely is not alone in offering a close analysis of how particular practices subordinate. See, e.g., Charles R. Lawrence III, If He Hollers Let Him Go: Regulating Racist Speech on Campus, 1990 DuKE L.J. 431 (1990); Mari J. Matsuda, Voices of America: Accent, Antidiscrimination Law, and a Jurisprudence for the Last Reconstruction, 100 YALE L.J. 1329, 1332 \& n.10 (1991) (invoking inethods of legal realism and sociology of law in analyzing accent discrimination); Siegel, Reasoning from the Body, supra note 20 (offering historical and contemporary analysis of abortion and its regulation that demonstrates how social structure and social representation interact to construct and rationalize contested practice), However, literature in the field often employs the discourse of subordination without acknowledging the extent to which the project proposed involves this kind of contestable theorization of particular practices. Cf. Colker, supra note 105, at 1066 (arguing anti-subordination framework presents "hard questions that cannot be addressed theoretically"; the article "set[s] forth a principle and a framework under which we can begin to answer these questions" which can only be addressed "in specific factual settings"). For one unusually forthright encounter with the complexities of elaborating an antisubordination theory, see Tracy E. Higgins, "By Reason of Their Sex": Feminist Theory. Post Modernisn and Justice, 80 CoRnel.l. L. REv. 1536, 1594 (1995) (urging Court and feminist legal theorists to abandon arguments that "rely on prepolitical conceptions of gender difference" and "acknowledge the exercise of power that is implicit in their own efforts to represent women politically and linguistically"). 
Are there risks in taking this historicizing vantage point on the interpretive conflicts in which we will inevitably engage as we argue about how to vindicate our normative commitments in our social practices? Absolutely. Our political culture prizes rule-like simplicity in its standards and individualism in its principles; the critical project to which this Lecture and Response point promises neither. Neither Post nor I have attempted to package the inquiries we have undertaken in doctrinal "bites." Indeed the sociological turn, at least as we each have explored it here, would seem to resist doctrinal assimilation precisely because it breaks from the ways that the dominant tradition has figured the meaning of equality for so many decades now.

But this seems to me as much a virtue as a vice. As one who read MacKinnon and Bell in delight at their refusal to engage debate on the terms law offered them, I want to defer conversation about exigencies of advocacy long enough to wrestle again with what we can fathom of the actual and the possible. For, as MacKinnon and Bell have so vividly demonstrated for us, if we can liberate the imagination from law, it is possible to enliven law with new imaginings. This, too, is doing law, for, in ways unore various than we can know, our intuitions about the justice of our practices would seem to be narrative. ${ }^{121}$

What, for me, is at stake in this critical encounter with the past? For all the abstract argument of this essay, I might trace its roots to stories I was told as child. My father first explained the civil rights movement, segregation, and slavery to me in terms of the post-Holocaustal injunction "Z'Chor," or Remember. In his stories, the forms of human injustice were plural, particular, and incommensurable, yet illuminated each other in disturbing ways. As I can now see, the questions his seemingly simple stories raised for me then continue to haunt my work today.

What if it turns out that what matters most are the stories that shape our intuitions of the just and reasonable, intuitions that theory and doctrine then articulate as norms, principles, and rules? And what if one of the most coinpelling of those stories in antidiscrimination law today is a certam narrative of progress in which we stand as ethical sophisticates equipped with vision and virtue that distinguishes us from our more ethically primitive forebears? This story invites us to form our identifications and commitments by repudiating the past, but can prove problematic precisely as it does so. Knowing ourselves as unimplicated by the past invites the kind of complacency that deadens the instinct to introspection and action both.

Moved perhaps by certain stories of my childhood, in my writing I have worked to deflate the kind of confidence this narrative engenders, a kind of confidence that comes from mistaking hindsight for a inoral virtue

121. See Siegel, Collective Memory, supra note 20; see also Balkin, Cultural Software, supra note 56, 203-10. 
rather than a critical vantage point. ${ }^{122} I$ have tried to decipher the past by asking, how are these ethically primitive forebears my forebears-that is, how might past generations of Americans have lived in worlds genealogically-linked to, or sociolegally like, my own? For me, asking such questions gives the practice of remembering both an ethical and a political dimension. No doubt, looking to the past and seeing continuity in the face of change can be sobering, even paralyzing; yet is it any more risky than looking to the past and seeing change in the face of continuity? As this nation's experience in recent decades illustrates, confidence in the redemptive possibilities of change can engender forms of self-satisfaction that may just as readily sap the collective will.

Without some awareness of our historical position, how are we to wield the rhetorical tools with which we reason about the justice of any community we might build? Even if this perspective on our project reveals that our tools are blunt and flawed, aren't we better off trying to find our way chastened by the knowledge that we, too, are fallible creatures whose principles and judgments are culturally contingent than in proceeding in willful disregard of that fact? Reckoning with our limitations need not involve relinguishing responsibility. Rather it presents us with a problem that is inescapably, perhaps even constitutively, human. As soon as a child has learned to say-"I did it," "He did it," and then "He made me do it"she has learned how to represent herself in a discourse of causes and a discourse of effects. Henceforth, she has a choice, and with it, the narrative resources in which to construct a self as acting or acted upon, agent, object, or any mix of the two. For all the sophistication she may thereafter acquire in representing herself to herself and to others, it is a choice that she can never again refuse.

122. See Siegel, Equal Protection, supra note 20, at $1146-48$. 